\title{
ARE INTERNET PRICES STICKY?
}

by Patrick Lünnemann and Ladislav Wintr 
EUROPEAN CENTRAL BANK

\section{WORKING PAPER SERIES}

NO 645 / JUNE 2006

EUROSYSTEM INFLATION

PERSISTENCE NETWORK

ARE INTERNET

PRICES STICKY?'

by Patrick Lünnemann ${ }^{2}$

and Ladislav Wintr ${ }^{3}$

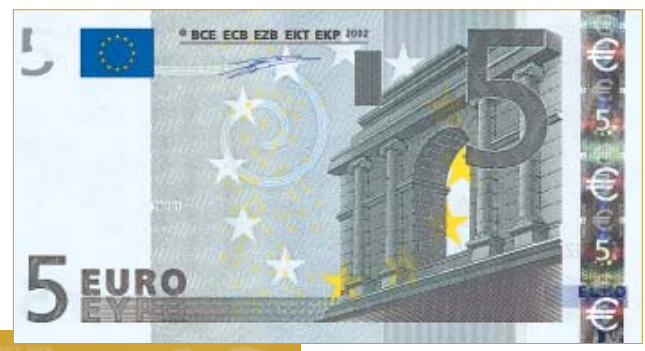

In 2006 all ECB

publications

will feature

a motif taken

from the

$€ 5$ banknote.

This paper can be downloaded without charge from http://www.ecb.int or from the Social Science Research Network electronic library at http://ssrn.com/abstract_id=907314

I The study has been undertaken in the context of the Eurosystem Inflation Persistence Network (IPN). We thank Silvia Fabiani and an anonymous referee as well as colleagues and members of the IPN for their constructive comments. The views expressed in this paper are personal views of the authors and do not necessarily reflect those of the institutions they are affiliated with.

2 Banque centrale du Luxembourg, 2, Boulevard Royal, L-2983 Luxembourg; e-mail: patrick.lunnemann@bcl.lu 3 Clark University, 950 Main Street, Worcester, MA 0I610, USA; e-mail: Iwintr@clarku.edu 


\section{The Eurosystem Inflation Persistence Network}

This paper reflects research conducted within the Inflation Persistence Network (IPN), a team of Eurosystem economists undertaking joint research on inflation persistence in the euro area and in its member countries. The research of the IPN combines theoretical and empirical analyses using three data sources: individual consumer and producer prices; surveys on firms' price-setting practices; aggregated sectoral, national and area-wide price indices. Patterns, causes and policy implications of inflation persistence are addressed.

Since June 2005 the IPN is chaired by Frank Smets; Stephen Cecchetti (Brandeis University), Jordi Galí (CREI, Universitat Pompeu Fabra) and Andrew Levin (Board of Governors of the Federal Reserve System) act as external consultants and Gonzalo Camba-Méndez as Secretary.

The refereeing process is co-ordinated by a team composed of Günter Coenen (Chairman), Stephen Cecchetti, Silvia Fabiani, Jordi Galí, Andrew Levin, and Gonzalo Camba-Méndez. The paper is released in order to make the results of IPN research generally available, in preliminary form, to encourage comments and suggestions prior to final publication. The views expressed in the paper are the author's own and do not necessarily reflect those of the Eurosystem.

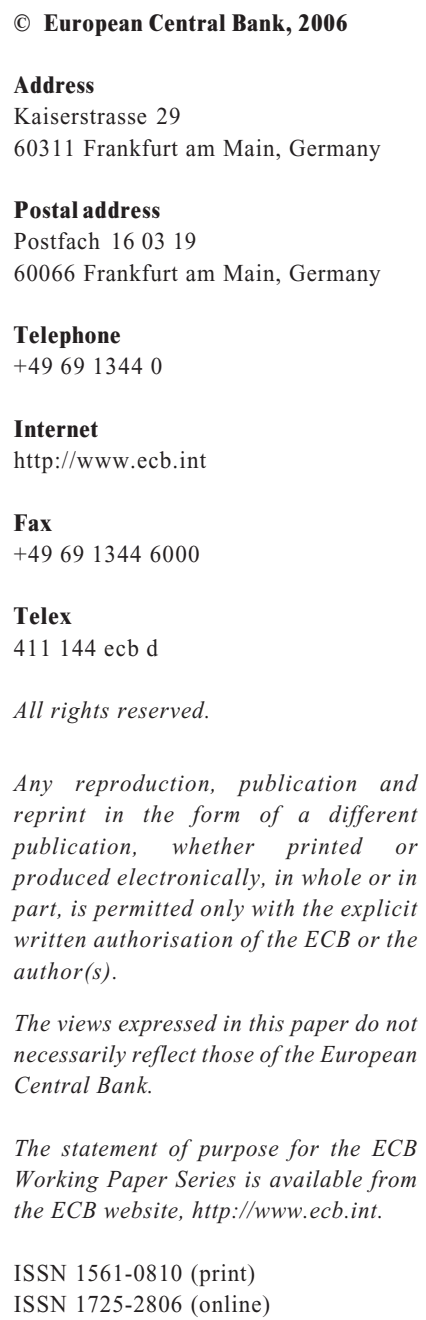

The views expressed in this paper do not necessarily reflect those of the European Central Bank. 


\section{CONTENTS}

Abstract

Non-technical summary

1 Introduction

2 Data, variables and methods

3 On the behaviour of Internet prices: stylized facts

3.1 Frequency of price change

3.2 Frequency of price change across shops and markets

3.3 Frequency of price change: the role of shipping and handling costs

3.4 Duration of price spells

3.5 Size of price changes

3.6 Internet versus brick stores

3.7 Comparison of identical models

3.8 Out-of-stock versus in-stock products

4 On the determinants of the probability of a price change

4.1 Model

4.2 Results across all product categories

4.3 Results for identical digital cameras

5 Conclusion

References

Appendix A

European Central Bank Working Paper Series 


\begin{abstract}
:
This paper studies the behaviour of Internet prices. It compares price rigidities on the Internet and in traditional brick-and-mortar stores and provides a cross-country perspective. The data set covers a broad range of items typically sold over the Internet. It includes more than 5 million daily price quotes downloaded from price comparison web sites in France, Germany, Italy, the UK and the US. The following results emerge from our analysis. First, and contrary to the recent findings for common CPI data, Internet prices in the EU countries do not change less often than online prices in the US. Second, prices on the Internet are not necessarily more flexible than prices in traditional brick-and-mortar stores. Third, there is substantial heterogeneity in the frequency of price change across shop types and product categories. Fourth, the average price change on the Internet is relatively large, but smaller than the respective values reported for CPI data. Finally, panel logit estimates suggest that the likelihood of observing a price change is a function of both state- and time-dependent factors.
\end{abstract}

Keywords: Price stickiness, Internet, price setting behaviour.

JEL: E31, L11. 
Non-technical summary

The assumption of sticky prices is an essential element of the New Keynesian economic theory that gives rise to business cycles. Recently, a series of studies conducted within the Eurosystem Inflation Persistence Network analyzed price rigidities using large data sets collected for the purpose of CPI calculation. The aim of this paper is to study price rigidities in one specific market environment, the Internet, and to supplement the evidence put together by the CPI micro price studies. We examine the issue from two perspectives - cross-country comparison of four European countries and the US and a comparison of price rigidities on the Internet and in the traditional brick-and-mortar stores.

For this purpose, we collected a data set containing over 5 million daily price quotes downloaded from price comparison web sites in France, Germany, Italy, the UK and the US. The data set covers the following groups of products: consumer and entertainment electronics, IT equipment, kitchen and household appliances, durables and services.

The following results emerge from our analysis. First, Internet prices in the European countries change on average more frequently than online prices in the US. This is in contrast to the recent findings from the micro price studies that univocally detect longer durations of price spells in the euro area using CPI data. Whereas retailers in the US might face smaller impediments to price adjustment than their European counterparts, this does not seem to be the case for genuine online stores. To the extent that cross-country differences in the degree of regulation were to be smaller on the Internet than in the traditional retailing (directly or indirectly, e.g. through smaller labour intensity), this can be interpreted as indirect evidence suggesting that price stickiness in the euro area's traditional retail sector can be at least partially explained by a more intrusive regulatory framework as compared to the US.

Second, prices on the Internet are not necessarily more flexible than prices in the traditional brick-and-mortar stores. On average, more than half of all Internet price spells fails within one month and on average 2.6 percent of Internet price quotes are changed every day. In the US, however, we find several product categories for which Internet prices last on average longer than the implied duration of off-line prices reported in existing research. This contradicts the prediction of the menu cost hypothesis given the lower cost of a price change on the Internet. In Germany, however, Internet prices last substantially shorter than reported in conventional CPI studies. In this context, with an increasing share of products sold via the Internet, a simple analysis of conventional brick store prices may - to an increasing degree - lead to underestimation of the true degree of consumer price flexibility.

Third, we found substantial degree of heterogeneity across shop types and product categories. Mail order companies and TV shops have the lowest likelihood of a price change, all else equal. This is in line with the prediction of the menu cost hypothesis based on the observation that these two shop types exhibit the highest cost of a price change among the shop types considered. The same argument implies that genuine Internet sellers should have the highest likelihood of a price change. This holds true with the exception of retailers in the US. Differences in the frequency of price change across product categories are more pronounced than differences across countries. Whereas this finding is well in line with findings from recent evidence from the analysis of CPI data in euro area countries, within the context of our study, it applies to a narrower set of consumer products and when taking into account data for the US. 
Fourth, the average size of price changes on the Internet is relatively large (5.4\%). Nevertheless, it is smaller than the respective values reported in the CPI data. Moreover, the most common price change interval on the Internet ranges from 0 to -1 percent, while in the CPI data one observes very few price changes in the interval from -2.5 to 2.5 percent. This corresponds to the prediction of the menu cost hypothesis.

Lastly, the panel logit estimates suggest that the likelihood of a price change is a function of both state- and time-dependent factors. In particular, the likelihood of a price change increases with the number of sellers offering the particular product and the percentage of sellers that changed the price of the same product on the previous day. Attractive prices, such as $€ 9.99$, and price quotes with high relative price level exhibit lower likelihood of a price change, all else equal. In general, the results also hold in a subsample of identical products sold in all countries. 


\section{Introduction}

The assumption of rigid price adjustment is a distinguishing feature of the New Keynesian Economics. As Clarida, Galí and Gertler (1999) state, "the approach [..] is based on the idea that temporary nominal rigidities provide key friction that gives rise to nonneutral effects of monetary policy." In this context, a large body of empirical research set out to investigate the extent of sluggish price adjustment and potential sources of price stickiness. Recently, Bils and Klenow (2004) pioneered an approach that employs disaggregate price observations to study price behaviour on the micro level. The key indicators of interest refer to the frequency of price change and the size of such changes. A rich set of information on ten euro area countries is provided by Dhyne et al. (2005). Their analysis is based on individual price quotes for a common sample of 50 products collected by the respective national statistical institutes. ${ }^{1}$ Even more detailed information is provided in a number of euro area country studies encompassing individual price data representing a large fraction of the respective national consumer price indices. The main findings from these studies suggest that consumer prices change relatively infrequently. In addition, price changes, once they take place, are sizeable relative to the aggregate inflation rate. In a similar vein, Vermeulen et al. (2005) summarize recent evidence on the behaviour of producer prices across selected euro area countries. ${ }^{2}$

In spite of the recent efforts, the micro evidence on the aggregate degree of price stickiness remains incomplete. Policy implications, though potentially important, remain difficult to identify. First, there is strong evidence pointing to a higher frequency of price adjustment in the US than in euro area countries (see Dhyne et al., 2005). Although a number of potential explanations have been put forward (ranging from different retail structures to differences in consumer preferences and others), the genuine underlying determinants have not been identified so far. A straightforward comparison of the behaviour of consumer prices between the euro area and the US is barely feasible at this stage. One may not exclude that differences with respect to the frequency of price change are due to differences in the choice of the elementary products, brands or models, different outlet structures, periods under investigation, differences with regard to the way prices are collected by the representative statistical institutes, etc. Second, recent survey evidence for the euro area suggests that both consumer and producer prices change relatively infrequently. In their summary of recent micro evidence, Álvarez et al. (2005) report that producer prices seem to be changed slightly more frequently than retail prices, which might suggest that the retail sector (or its structure) adds to the sluggishness of price adjustment. However, evidence on the role of the retail sector with regard to the flexibility of prices is inconclusive so far. To the extent that genuine Internet outlets typically lack conventional retail distribution channels, comparing the behaviour of Internet and highstreet prices may yield further information on the role of retailing. Third, evidence from surveys among firms in a number of euro area countries suggests that the sluggishness of price adjustment may depend on the degree of (perceived) competitiveness (see Fabiani et al., 2005). ${ }^{3}$ In their analysis of price setting behaviour based on Spanish micro producer price data, Álvarez et al. (2005c) find that the higher (lower) is the degree of competition, the higher (lower) is the frequency of price

1 The countries under study are Austria, Belgium, Finland, France, Germany, Italy, Luxembourg, the Netherlands, Portugal and Spain. In addition to a comparison of selected summary statistics for a 50 common product sample, Dhyne et al. (2005) discuss empirical evidence from selected detailed country-specific studies.

2 Vermeulen et al. (2005) draw primarily on the findings of detailed country studies based on the analysis of individual producer prices. The countries under study are Belgium, Germany, Italy, Portugal and Spain.

3 In their paper, Fabiani et al. (2005) summarize empirical evidence reported in country-specific studies based on firm surveys. The detailed country studies cover Austria, Belgium, France, Italy, Luxembourg, the Netherlands, Portugal and Spain. 
changes. Micro consumer price studies, however, so far provide only very limited evidence on the role of competition on the degree of price stickiness (see, for example, Lünnemann and Mathä, 2005b).

This paper addresses a number of issues arising from the analysis of conventional consumer prices collected by statistical institutes (and other sources). It does so by studying the behaviour of individual prices downloaded from Internet comparison sites. By downloading Internet prices one may substantially streamline the burden of collecting prices in brick stores, either through "price officials" or via the national statistical institutes. Restricted access to the statistical institutes' individual price records and the administrative burden of collecting prices manually have been a major obstacle to a broad assessment of consumer price behaviour in the past. Due to these limitations, conventional studies on price behaviour were mostly limited to a small number of products. Cechetti (1986) studies newsstand prices of magazines. Lach and Tsiddon (1992) analyse a selection of food products sold in grocery or liquor stores in Israel. Kashyap (1995) presents estimates of the size, frequency and synchronisation of price changes for selected items offered in retail catalogues. Borenstein et al. (1997) use city-level retail and wholesale gasoline prices. Dutta et al. (2000) examine the extent of price rigidity using storelevel scanner data for a small selection of food products. Ratfai (2003) uses a selection of processed meat products in Hungary in a monthly panel data set. Bergen et al. (2004) study item-pricing laws based on supermarket prices.

Since its introduction, the Internet has greatly affected consumer decisions (Ellison and Ellison, 2005). With respect to consumers, it offers product descriptions, renders price comparisons (across regions, shops and models, as well as over time) a matter of mouse clicks and essentially increases market transparency and the number of potential customers. Over the past decade, penetration rates of web related infrastructure and tools increased rapidly. In particular in the US the e-retailing industry has matured and is becoming an increasingly profitable and highly efficient merchandising channel. In 2003, the top 300 web merchants recorded an estimated 11.4 billion visits to their sites, leading to estimated USD 435 million online sales. For 2003, the top 300 web merchants reported an impressive average sales ticket of USD 92 (www.internetretailer.com). The U. S. Census Bureau estimated that in the third quarter of 2005 retail e-commerce sales accounted for 2.3 percent of total retail sales, up from less than 1 percent in the same quarter of 2000. In the third quarter of 2005 estimated e-commerce sales increased by 26.7 percent from the same quarter of 2004, whereas total retail sales increased by a mere 8.5 percent in the same period (U.S. Census Bureau, 2005). ${ }^{4}$ Forrester Research forecasts double-digit growth rates for US online retail sales from 2005 to 2010 (www.epsltd.com). The four largest Western European countries are all at different stages of e-commerce development. The number of online buyers as a fraction of Internet users was 45 percent in France (as of the fourth quarter of 2004), 54 percent in Germany (June 2005) and 62 percent in the UK (June 2005). ${ }^{5}$ In 2004, the cumulated B2C e-commerce revenue generated in the four largest Western European countries was roughly $€ 65$ billion (European Information Technology Observation, EITO). According to eMarketer, online shopping and purchasing is on the rise even in countries seeing deteriorating off-line retail sales. In 2004, online purchasing in France and the UK surged by roughly 50 and 30 percent, respectively. With regard to the four largest Western European countries, EITO expects retail e-commerce markets to increase by almost 300 percent between 2004 and 2008.

4 In 2003, the sales of the US top 100 retail web sites accounted for $3.4 \%$ of the total corporate sales of the retail chains, catalogue companies and manufacturers which own these sites. (www.internetretailer.com).

5 Note the fraction of online buyers in Internet users in the US was 61 percent (ages 14+, April 2005). Source: eMarketer. 
This change in the traditional outlet structure of a representative consumption basket, so far, had very little (if any) impact on the price collection practices of national statistical institutes as in most European countries national statistical institutes continue collecting prices in conventional brick stores, Internet prices rarely enter the compilation of consumer price indices. ${ }^{6}$ Although an increasing number of studies utilizes high-frequency data on prices collected from the Internet, the data were mostly used to study other aspects of pricing, such as price dispersion (e.g. Baye et al., 2002), price levels (e.g. Brynjolfsson and Smith, 2000) and price-setting behaviour (e.g. Kauffman and Wood, 2000). Chevalier and Goolsbee (2003) collected both price and quantity data from online booksellers to estimate the magnitude of retail outlet substitution bias in the CPI due to the rise of Internet sales. Only few studies focus on price rigidity on the Internet. Prices of books collected from Amazon and Barnes \& Noble were used by Chakrabarti and Scholnick (2005), who report weekly frequency of price changes of 4 percent. Bergen et al. (2005) collected data from the same online booksellers with daily frequency. They report that on average a book changed its price on the Internet approximately every 90 days.

At the current stage, studies on Internet prices mostly relate to the US, whereas the evidence on price behaviour in euro area countries remains scarce. Internet prices seem well suited to the analysis of consumer prices in the flavour of Bils and Klenow (2004) and Dhyne et al. (2005). They can be collected in a very flexible manner, changes to the download procedure may be implemented at any time without formal re-arrangements with statistical institutions. In addition, the downloading algorithm can be easily extended with respect to the sample period, set of product types, sample size, geographical area covered, etc. Prices may be collected with high frequency (in almost real time), and at very low processing cost.

Apart from the (almost) frictionless environment the Internet theoretically offers to consumers via immediate availability of product information and price comparisons at very low search cost, Internet markets abstract from a number of structural characteristics of conventional market places (such as the role and the structure of the retail sector). In addition, some potential sources of sluggish price adjustment in brick stores - such as true type menu costs - become less important (though not irrelevant) for online sellers ${ }^{7}$. Comparing the degree of price stickiness between brick stores and the Internet (across countries) may, thus, contribute indirectly to better understanding the driving factors of price stickiness.

The aim of this paper is as follows. First, to assess the degree of price stickiness in Internet markets given their increasing importance in total consumer expenditures. Second, given the enhanced comparability of Internet prices, to compare the degree of stickiness in Internet stores across five major industrial countries, including the US, UK and three euro area countries. Third, given their short cut to traditional retailing, to compare the degree of stickiness of Internet prices with estimates for traditional retail markets. Fourth, to determine factors influencing the adjustment of Internet prices. The structure of the paper follows the objectives set above.

\section{Data, variables and methods}

In total, more than 5 million price quotes were collected from price comparison web sites in France (www.kelkoo.fr), Italy (www.kelkoo.it), Germany (www.kelkoo.de), the UK

6 Depending on the relative importance of online shopping for consumer expenditures with regard to specific product categories, the US Bureau of Labor Statistics (BLS) may proceed in collecting prices from the Internet. Whereas the fraction of price quotes collected from the Internet is still very small, the BLS closely monitors changes to the outlet structure relevant for consumer expenditures in general and the role of online shopping in particular.

7 In particular, STP in Internet markets promises very low costs of changing prices as well as of printing and delivering new price tags (see Levy et al., 1997 and Dutta et al., 1999). 
(www.kelkoo.co.uk) and the US (www.bizrate.com). Prices were downloaded at daily frequency between December 2004 and December $2005 .^{8}$

In general, all prices quoted for a group of product categories at the respective country-specific site were collected, regardless of whether these were offered on all sites or not. The choice of products is limited to products offered on the Internet by a sufficiently large number of outlets. The data set covers consumer electronics (DVD players, LCD TVs, Mini-Systems), entertainment electronics (portable mp3 players, digital cameras), IT (laptops, scanners), kitchen appliances (coffee machines, microwave ovens), small household appliances (vacuum cleaners), durables (washing machines, fridges) and services (photo development).

Recent research based on micro data suggests that service prices are particularly important with regard to price rigidity in the euro area (see, for example, Álvarez et al., 2005a). Unfortunately, service prices are particularly difficult to collect from the Internet. First, in particular in the European countries, the number of services offered on the Internet remains quite limited so far (mostly travel accommodation, package tours, airline tickets, rental cars, etc.). Second, the (tradable) services offered on the web are heterogeneous in kind and often very specific terms and conditions apply (also as a function of the socio-economic characteristics of the client). In many cases the information available does not define the product uniquely. Tracking changes to such prices over time is extremely difficult and subject to strong seasonal patterns and changes in the product quality. Against this background, we also study the behaviour of prices for photo development as one specific type of services offered on the web. Photo development services are relatively well defined (primarily depending on the format) and unique prices are mostly applicable to all types of private customers. Contrary to the Kelkoo sites studied for the four largest European economies, Bizrate does not compare the prices of photo development services in the US. The photo development category turned out to be strikingly different from the remaining categories, in particular as the number of price changes observed is very small. For this reason we exclude this category from the analysis below, unless explicitly specified (for example in section 3.6).

Table 1: Sample size by country and by product category

\begin{tabular}{lrrrrrr}
\hline & \multicolumn{1}{c}{ DE } & \multicolumn{1}{c}{ FR } & \multicolumn{1}{c}{ IT } & \multicolumn{1}{c}{ UK } & \multicolumn{1}{c}{ US } & Total \\
\hline \hline Coffee makers & 26163 & 29870 & 7344 & 9482 & 118579 & 191438 \\
Digital cameras & 162962 & 47902 & 92910 & 105278 & 536629 & 945681 \\
DVD players & 35409 & 25889 & 17483 & 16497 & 133729 & 229007 \\
Fridges & 149391 & 206310 & 24844 & 174632 & 264970 & 820147 \\
Laptops & 152121 & 82445 & 89077 & 7486 & 189699 & 520828 \\
LCD TVs & 35845 & 38957 & 37880 & 60254 & 231929 & 404865 \\
Microwave ovens & 27241 & 75711 & 6191 & 54818 & 30148 & 194109 \\
Mini-systems & 17904 & 21984 & 6404 & 24858 & 29011 & 100161 \\
MP3 players & 25029 & 52160 & 17288 & 24088 & 172995 & 291560 \\
Scanners & 67815 & 38181 & 29371 & 7484 & 251594 & 394445 \\
Photo development & 1271 & 5453 & 1830 & 4698 & NA & 13252 \\
Vacuum cleaners & 31717 & 62918 & 4840 & 32095 & 533578 & 665148 \\
Washing machines & 66613 & 168845 & 21410 & 207855 & 38000 & 502723 \\
\hline Total & $\mathbf{7 9 9} \mathbf{4 8 1}$ & $\mathbf{8 5 6 \mathbf { 6 2 5 }}$ & $\mathbf{3 5 6} \mathbf{8 7 2}$ & $\mathbf{7 2 9} \mathbf{5 2 5}$ & $\mathbf{2 5 3 0 \mathbf { 5 6 1 }}$ & $\mathbf{5 2 7 3 \mathbf { 3 6 4 }}$ \\
\hline
\end{tabular}

8 Except for section 3.3, we consider prices without shipping and handling costs because these were not quoted for all observations. Price flexibility can manifest itself in both the price and the non-price component of the product (shipping costs, delivery times etc.). Unfortunately, non-price elements are not always clearly defined by the sellers and can also depend on the location of the buyer (especially in the US shipping costs often vary with distance from the seller). 
Given the differences in market size, preferences, etc., the number of observations for product types varies across countries (see table 1 above). Approximately 48 percent of all price quotes relate to the US. The share of the euro area countries ranges from approximately 7 percent (Italy) to more than 15 percent (France and Germany). Not only the number of products offered on the web, but also the average number of shops listing a given product is substantially larger in the US than in the European countries. This has implications for the definition of the market environment (see sections 3.2 and 4.2 ).

Overall, we analysed price quotes from more than 1050 outlets. In general, five types of sellers are distinguished. Genuine web stores are shops that primarily offer their products on web sites. Internet outlets maintaining up to two off-line establishments (brick-and-mortar shops, showrooms, or pick-up points) in addition to their online store are considered a separate shop type. Retail outlets are characterised by three or more brick stores within a given country (in addition to their online store). Another category of shops consists of online market places maintained by manufacturers. Finally, mail order companies are considered a distinct type of outlet. ${ }^{9}$ Prices listed by auction houses (like eBay) were excluded from the data set, as well as used and refurbished items.

Figure 1: Sample structure: Price quotes per shop type and country

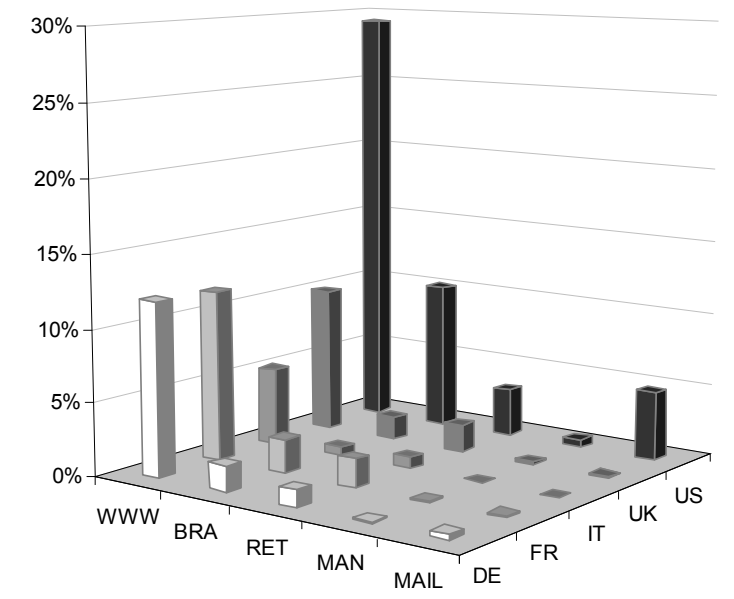

Remark: www, bra, ret, man and mail characterise genuine online stores, online stores with few branches, stores with numerous highstreet stores, manufacturers and mail order companies, respectively.

As illustrated in figure 1, approximately two out of three price quotes are collected from genuine online shops. Retailers account for approximately 9 percent of all price quotes, the corresponding share for mail order companies is roughly 5 percent. With slightly more than 27000 observations, producers provide less than 1 percent of all price quotes studied and constitute the smallest shop type category. The shop structure differs considerably across countries. Although genuine online stores represent the largest number of price quotes in all five countries, their fraction in the total number of observations ranges from 61 percent in the US to 79 percent in Italy. Whereas in the US and in Germany the fraction of price quotes collected from retailers is relatively small ( 7 and 8 percent, respectively), they account for almost one out

$9 \quad$ Throughout the paper, price quotes listed by outlets of unknown shop type are not considered. Within section 4 , outlets offering products primarily through TV or home shopping are considered a separate shop type. As this shop type is found in the data for the US only, it is of limited use for the summary statistics. 
seven price quotes collected for the UK. The fraction of price quotes collected from mail order companies is relatively important in the US (almost 10 percent), whereas we did not consider any price quotes from mail order companies in Italy.

Some of the product categories studied in this paper can be classified into the broader product classes covered by national consumer price indices. In particular, washing machines, vacuum cleaners, coffee makers, refrigerators and microwave ovens belong to COICOP category 0503, television sets, HiFi systems, MP3 players, DVD players, laptops and digital cameras to COICOP 0901 and photo development to COICOP 0904. As the range of products listed on the Internet is limited, the set of products considered represents but a small fraction of total consumer expenditures. A strict upper bound for the relative importance of these product categories can be derived from the expenditure weights of the corresponding COICOP classes. In 2005, the relative share of the COICOP classes 0503, 0901 and 0904 in total expenditures according to the HICP ranged from 4.4 (Italy) to 6.6 (UK) percent. The corresponding shares for Germany and France were 5.5 and 6.1 percent, respectively. Hence, our findings are neither directly comparable to the aggregate findings from CPI studies, nor are they representative for the full consumption basket. For each of the price quotes collected, regardless of the country, the data set entails the following information: product code, brand and model description, product category, outlet code, price quoted, date and time the observation was downloaded and information about the shipping and handling costs. For the US, the data set also includes a categorical variable indicating the availability of the product (in stock, out of stock, etc.) as well as an outlet rating indicator as calculated by Bizrate based on customer feedback.

In analogy to micro price studies of brick-and-mortar stores, a price trajectory denotes a series of price quotes for a specific product in a given outlet. Price trajectories can be divided into price spells, i.e. periods of constant price for a specific product in a specific outlet.

Similar to the indicator set commonly provided by the recent studies of consumer prices at the micro level (see, for example, Baumgartner et al., 2005; Álvarez and Hernando, 2005; Aucremanne and Dhyne, 2004), we focus on the frequency of price change (or the implied duration) and the size of such price changes. As the theoretical research points towards the importance of downward price rigidity in particular, we also distinguish between price decreases and price increases. Hereafter, $\mathrm{p}_{\mathrm{ijt}}$ denotes the price of product $i$ quoted by shop $j$ at time $t$. The frequency of price change for a group of price quotes $k, \mathrm{~F}_{\mathrm{k}}$, is computed as the fraction of prices in the set $k$ that changed during the sample period. ${ }^{10}$

Note that, as we collect data at daily frequency, we allow for frequencies of price change higher than monthly. Hence, ceteris paribus, we would expect somewhat smaller measured frequencies of price change than those obtained by conventional micro price studies based on CPI data.

Assuming stationarity and homogeneity of price change behaviour, the inverse of the frequency of price changes converges asymptotically to the average duration of a price spell (see e.g. Baudry et al., 2004). In continuous time representation, and assuming a constant probability of price change throughout the day, the average duration $D_{k}^{a v}$ and median duration $D_{k}^{\text {med }}$ can be written respectively as

10 When computing the frequency of price change, in cases where, for a given shop and a given product, the price quote disappears and re-appears after a period no longer than five days at an identical price, the trajectory is considered to continue. In theory, this might imply a measured frequency of price change slightly below the true frequency. However, the likelihood of prices to change twice within five days is very small, given the average frequency of price change. In addition, for all our computations (i.e. summary statistics and logit model) we require for each trajectory that the share of observations missing due to gaps in the total number of price quotes is smaller than 10 percent. 


$$
D_{k}^{a v}=-\frac{1}{\ln \left(1-F_{k}\right)} \quad \text { and } \quad D_{k}^{m e d}=\frac{\ln (0.5)}{\ln \left(1-F_{k}\right)}
$$

In addition to the overall frequency of price change, we compute survivor functions and hazard rates by product category and by country. Survivor functions and hazard rates generalise on the frequency of price change as they take into account the length of a price spell. For each duration $d$, the survivor function $S(d)$ gives the probability that a price spell will last to or beyond the specified time $d$, formally $\mathrm{S}(d)=\operatorname{Prob}(D \geq d)=1-F(d)$, where $F(\cdot)$ is the cumulative distribution function of the completed spell duration $D$. Hereafter, all estimates of the survivor function are Kaplan-Meier product-limit estimates. The hazard rate $h(d)$ reflects the conditional probability that a price spell lasting until duration $D$, will end instantaneously after the completion of spell duration $D$. The hazard function can be written as

$$
h(d)=\lim _{\Delta d \rightarrow 0} \frac{P(D<d+\Delta d \mid D \geq d)}{\Delta d}=\frac{f(d)}{1-F(d)},
$$

where $f(\cdot)$ denotes the probability distribution function corresponding to $F(\cdot)$. Empirical studies on individual prices typically find a downward sloping aggregate hazard function (see, for example, Dhyne et al, 2005). Álvarez et al. (2005b) point out that if micro price data are generated by heterogeneous firms obeying to standard models of price setting behaviour (e.g. the widely used time-dependent models by Calvo and Taylor), aggregate hazard functions are (nearly always) decreasing. In addition, based on the aggregation of agents that follow state-dependent pricing rules à la Dotsey, King and Wolman (1999), they show that heterogeneity does not necessarily yield a downward sloping aggregate hazard function.

In order to provide maximum comparability with the recent micro CPI studies for brick-andmortar stores, we define the size of a price change as the log difference between two consecutive price quotes within a price trajectory. Log differences yield identical sizes of price increases and decreases if price changes become reversed, which is particularly convenient when dealing with such observations (on the importance of price change reversals, see section 3.5).

\section{On the behaviour of Internet prices: stylized facts}

\subsection{Frequency of price change}

In spite of the relatively small costs of updating prices on the Internet, ${ }^{11}$ in general, online stores do not adjust prices at daily frequency. This applies to all countries and all product categories considered. On average, across all countries considered, the daily frequency of price change is approximately 2.6 percent, i.e. 2.6 percent of price quotes change on an average day. At the country level, the highest frequency of price change is obtained for Italy (approximately 3.8 percent), while the UK exhibits the lowest daily frequency of price change (2.1 percent). The average frequencies of price change in France, Germany and the US are approximately 3.1, 2.7 and 2.5 percent, respectively. Given the differences in the product composition observed across countries (see also table 1), ${ }^{12}$ a different result emerges when applying an identical (unique) weighting of all product categories. With equal uniform product weights, the highest frequency of

11 Listing prices on the web, as such, does not have any impact on the costs of reviewing prices though.

12 For example, whereas in France and in the UK 24 percent of the price quotes relate to fridges, their share is only 10 percent in the US. 
price change is observed in France (3.1 percent), whereas the lowest frequency of price change is recorded in the US ( 2.1 percent). The average frequency of price change for the three euro area countries considered here ("EA3" hereafter) is roughly 2.6 percent, the corresponding figure for the four large western European countries ("EU4" hereafter) is 2.5 percent.

Based on the equally-weighted frequencies of price change, the implied median duration ranges from 25 days (France) to 68 days (US). The weighted average implied durations for the EA3 and the EU4 are 31 days and 33 days, respectively. This result is at odds with the findings from micro CPI studies. First, the numbers are substantially lower than the implied duration times obtained by Bils and Klenow (2004) for the US (7 months) and by Dhyne et al. (2005) for the euro area countries (approximately 1 year). ${ }^{13}$ Second, the CPI studies unanimously indicate a substantially higher frequency of change in US consumer prices than in the euro area. At the same time, there is no pair of countries that would share the same ranking of product categories considered. Moreover, no country scores better than any other country for all product categories considered. Across all product categories, the cumulated rank (low number representing the highest frequency of price change) is smallest for France and Italy and largest for the US. This is illustrated in figure 2 below summarising our results with regard to the frequency of price change by country. The red diamonds represent the unweighted average frequency of price change across the product categories considered here. The blue vertical lines illustrate the spread between the lowest frequency of price change and the highest frequency of price change across all 12 product categories. The green bars indicate the country rank cumulated across all 12 product categories, where - for a given product category - rank 1 characterises the country for which the highest frequency of price change is observed. The high average frequency for France is primarily due to the absence of very low average frequencies of price change, rather than extremely high frequencies for some product categories.

Figure 2: The daily frequency of price change (averages over product categories)

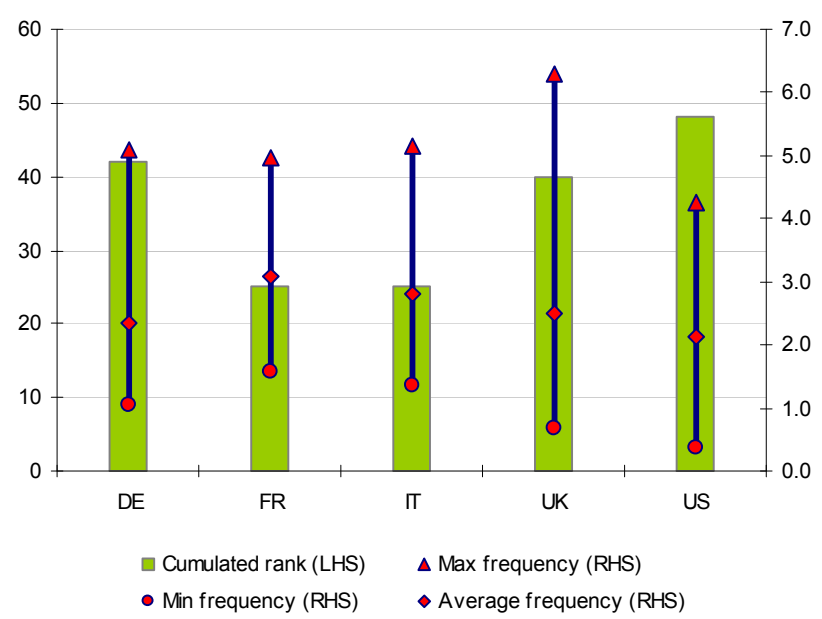

Figure 3 below shows that at the product category level, the (across countries) average frequency of price change ranges from 1.3 (coffee makers) to 4.3 percent (laptops). Next to coffee makers, we find relatively low frequencies of price adjustment for microwave ovens (1.5 percent), mini-systems (1.5 percent), vacuum cleaners (1.6 percent) and fridges (1.6 percent). One reason might be their relatively long product life cycle due to slower rate of technological

13 Note that common CPI prices are collected at monthly frequencies. Implied durations obtained from daily frequencies of price change on one hand and from monthly frequencies of price change on the other hand may not be perfectly comparable. 
decay of these items as compared to the remaining products. Across all product-country combinations, the frequency of price change ranges from 0.4 percent (microwave ovens in the US) to 6.3 percent (LCD TV sets in the UK). Similar to the country ranking, no product category ordering holds across all countries. Among euro area countries, however, the highest frequency of price change is observed for laptops, whereas coffee makers reveal the lowest frequency of price change. In the US, digital cameras reach the highest frequency of price changes (LCD TV sets in the UK). Considering all countries, digital cameras, MP3 players, LCD TVs and laptops rank fifth or better. In contrast, mini-systems, microwave ovens and coffee makers rank sixth or worse.

Figure 3: The daily frequency of price change (averages over countries)

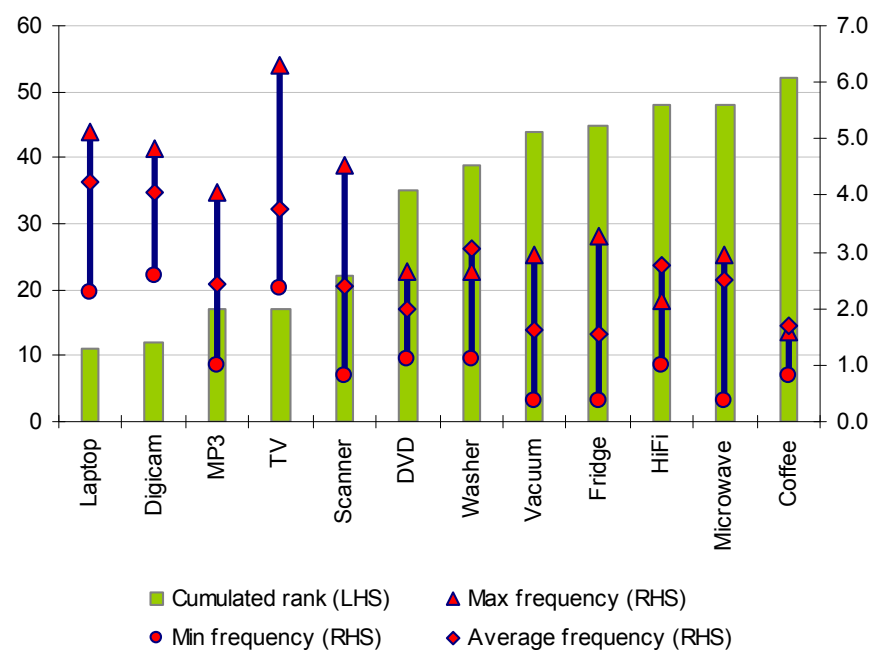

The results reported in this section so far exclude the photo development category. As a matter of fact, over a 4-month download period, only few price changes had been observed. Among the 13000 price quotes collected for all EU4 countries, a mere 14 price changes were recorded. France accounts for more than 40 percent of price quotes in this category but no single price change was found. In Germany and Italy, we recorded 1 and 2 price changes, respectively. Finally, 11 price changes were observed in the UK, implying a daily frequency of price change of 0.2 percent. These findings may suggest that e-retailing may well contribute to the flexibility of prices for consumer goods, but not so for consumer services. This may, in turn, suggest that the traditional retail sector in the euro area adds stickiness to otherwise more flexible consumer goods prices, but not to (inherently) sticky consumer services prices.

In terms of the frequency of price change, we find that the differences across countries are less pronounced than the differences across product categories. Across countries, the spread in the frequency ranges from 0.7 (coffee makers) to 3.1 percentage points (LCD TV sets). Similarly, across product categories, the frequency spread lies between 3.4 (France) and 5.6 percentage points (UK). Not only the maximum spread across countries is smaller than the minimum spread across product categories, but also, for each product category (except for the microwave ovens, fridges and vacuum cleaners), the spread (between countries) is smaller than the average frequency of price change. In contrast, for all countries, the spread (between product categories) is larger than the average frequency of price change. These results support the evidence from the micro CPI-based country comparisons suggesting that cross-country differences are dominated by differences across product types (Álvarez et al., 2005a, Dhyne et al, 2005). When 
considering Internet prices, however, this conclusion holds for a much narrower range of consumer products and not only for the euro area countries but also when incorporating the US.

At the product category-country level, the implied median duration of price spells lies between 17 days (LCD TVs in the UK) and slightly more than half a year (microwave ovens in the US). For more than 1 out of 3 product category-country combinations, the implied average duration is less than one calendar month, the frequency of price collection typically underlying the micro CPI studies. For the implied median duration, the same applies to one out of two product categorycountry combinations. For some product category-country combinations, the implied duration suggests two price changes per month (e.g. LCD TVs in UK).

Dhyne et al. (2005) report that a common feature of conventional retail prices is that prices decline less frequently than they increase. In general, they find that price reductions represent approximately four out of ten price changes. With Internet prices, price reductions seem to be more frequent. ${ }^{14}$ Across all category-country combinations, the share of price reductions in total price changes ranges from 40 percent (microwave ovens in the UK) to 87 percent (LCD TVs in the UK). Across all product categories and countries, the average share of price reductions is approximately 62 percent. At the country level, the average share of price reductions in total price changes ranges from 58 percent (Italy) to 66 percent (Germany). Again, this finding may not be a property inherent to the Internet, but rather might reflect the peculiarities of products typically sold via the web, in particular consumer electronics. Subject to a more or less rapid process of technological obsolescence, in all countries considered, digital cameras, laptops, portable MP3 players and LCD TVs reveal more frequent price reductions than price increases. The same applies to microwave ovens and fridges only in three countries. For a comparison of the frequency of price change and the relevance of reductions between Internet prices and prices collected from brick-and-mortar shops see section 3.6.

\subsection{Frequency of price change across shops and markets}

We find substantial variation in the frequency of price change across shops and shop types. The average frequency of price change across all shop types and all countries considered is approximately 2.1 percent (see table 2). The average frequency of price change by shop is highest in Italy ( 3 percent) and lowest in the US (1.6 percent). ${ }^{15}$ The distribution of the average frequency of price change across shops reveals that a substantial share of shops, on average, rarely undertakes price changes. In the US, in particular, approximately 47 percent of all shops did not change a single price during the sample period. In France, Germany and UK, the share of shops that did not change a single price lies between 17 percent and 22 percent. In contrast, in Italy, only one out of ten firms kept their prices constant. For all countries considered, the share of firms refraining from price increases is higher than the corresponding share for price reductions. The $95^{\text {th }}$ percentile of the frequency of price change ranges from 7 percent in the US to 10.7 percent in the UK.

14 Whereas at the aggregate level this share applies to practically all of the ten euro area countries studies in Dhyne et al. (2005), the share of price reductions in total price changes varies substantially across product categories. On the one hand, the share of price reductions is substantially lower for service products (roughly 20 percent). On the other hand, a more detailed analysis of micro CPI prices may yield a substantially higher fraction of price reductions in total price changes for household appliances (see, for example, results by Hoffmann et al, 2006 and their discussion in section 3.6).

15 The large discrepancy is due to a relatively large number of shops with zero frequency of price change that, at the same time, list a small number of price quotes. 
Table 2: Average frequency of price change: distribution over shops

\begin{tabular}{|c|c|c|c|c|c|c|c|c|c|}
\hline & \multicolumn{3}{|c|}{$\begin{array}{l}\text { Average frequency } \\
\text { of price }\end{array}$} & \multicolumn{3}{|c|}{$\begin{array}{l}\text { Share of firms with zero } \\
\text { frequency of price }\end{array}$} & \multicolumn{3}{|c|}{$\begin{array}{l}\text { 95th percentile of } \\
\text { frequency of price }\end{array}$} \\
\hline & Change & Increase & Reduction & Change & Increase & Reduction & Change & Increase & Reduction \\
\hline DE & 2.5 & 0.9 & 1.6 & 17 & 26 & 21 & 7.5 & 3.4 & 5.2 \\
\hline FR & 2.3 & 0.8 & 1.5 & 22 & 30 & 23 & 8.3 & 3.1 & 5.1 \\
\hline IT & 3.0 & 1.0 & 2.0 & 10 & 20 & 12 & 7.9 & 3.5 & 5.7 \\
\hline UK & 2.7 & 1.0 & 1.7 & 20 & 36 & 23 & 10.7 & 2.0 & 6.7 \\
\hline US & 1.6 & 0.6 & 1.0 & 47 & 57 & 50 & 7.0 & 2.6 & 4.7 \\
\hline EA3 & 2.6 & 0.9 & 1.7 & 17 & 26 & 19 & 7.9 & 3.3 & 5.3 \\
\hline EU4 & 2.6 & 0.9 & 1.7 & 17 & 28 & 20 & 8.6 & 3.0 & 5.7 \\
\hline
\end{tabular}

At the level of the shop type, on average, the highest frequency of price change is obtained for genuine online stores (3.2 percent) whereas mail order companies change prices most infrequently (1 percent). With regard to the frequency of price change, online stores maintaining brick-and-mortar selling points rank second (2.2 percent), whereas manufacturers home in third (2.0 percent). Retailers with online presence are characterised by below average frequency of price change (1.9 percent). Although no unanimous ranking of shop types with respect to the frequency of price change exists, we find for all five countries that genuine web stores rank no lower than second whereas mail order companies rank fourth or lower (see figure 4 below).

Figure 4: Frequency of price change per country and shop type (relative to the country average)

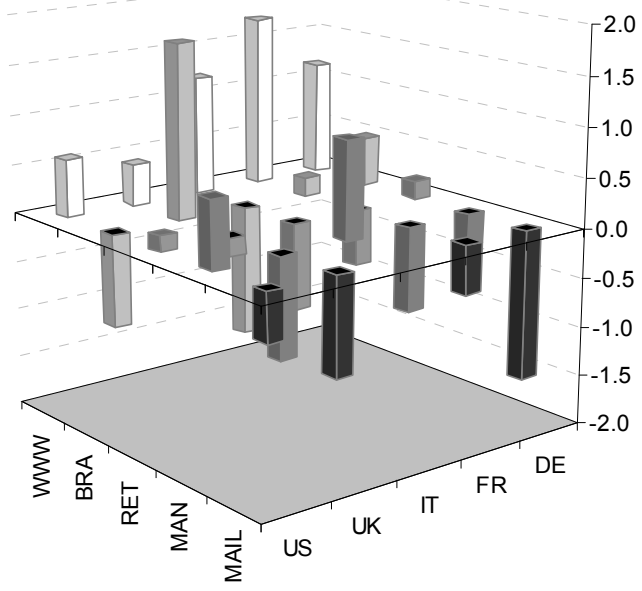

Remark: www, bra, ret, man and mail characterise genuine online stores, online stores with few branches, stores with numerous highstreet stores, manufacturers and mail order companies, respectively.

Table 3 illustrates the average frequency of price change as a function of the relative price level. For the purpose of this exercise, shops are classified into one of the four relative price categories (low, mid-low, mid-high, high). Shops are classified low-price if, for a given product and date, the price quoted is lower than the $25^{\text {th }}$ percentile of prices. Mid-low, mid-high and highprice shops are defined according to the $25^{\text {th }}$, the $50^{\text {th }}$ and the $75^{\text {th }}$ percentile. ${ }^{16}$ Overall, the frequency of price change decreases with the relative price level. For all countries we find that

16 Note that the relative price categories refer to the product price without shipping and handling costs. To the extent that shipping and handling costs differ across shops (see also section 3.3), shop rankings according to the total price (product price including shipping and handling costs) may lead to different results. 
very competitive shops (i.e. low-price shops) reveal the highest frequency of price change. Whereas this holds similarly for price reductions, the frequency of price increases is not monotonically related to the relative price level. The extent to which low-price shops change prices more often than shops from the upper tail of the price distribution differs across countries though. In the US, the frequency of price change corresponding to low-price shops is more than three times the average frequency of high-price shops. In France, the frequency of price change practiced by low-price shops exceeds the one observed for high price shops by "only" 60 percent.

Table 3: The average frequency of price change and the relative price level

\begin{tabular}{llccc}
\hline Country & $\begin{array}{c}\text { Relative } \\
\text { price } \\
\text { level }\end{array}$ & Change & $\begin{array}{c}\text { Frequency of price } \\
\text { Increase }\end{array}$ & Reduction \\
\hline \hline DE & Low & 3.1 & 0.8 & 2.3 \\
& Mid-low & 2.4 & 0.8 & 1.6 \\
& Mid-high & 1.7 & 0.7 & 1.0 \\
& High & 1.4 & 0.8 & 0.6 \\
FR & Low & 3.6 & 1.1 & 2.6 \\
& Mid-low & 2.8 & 1.0 & 1.7 \\
& Mid-high & 2.7 & 1.1 & 1.6 \\
& High & 2.3 & 1.2 & 1.0 \\
IT & Low & 7.3 & 2.1 & 5.2 \\
& Mid-low & 3.6 & 1.2 & 2.5 \\
& Mid-high & 3.0 & 1.4 & 1.6 \\
& High & 2.6 & 1.6 & 1.0 \\
UK & Low & 2.6 & 0.6 & 2.1 \\
& Mid-low & 2.0 & 0.7 & 1.4 \\
& Mid-high & 1.4 & 0.7 & 0.7 \\
& High & 1.1 & 0.7 & 0.3 \\
US & Low & 6.7 & 1.2 & 5.5 \\
& Mid-low & 3.9 & 1.3 & 2.6 \\
& Mid-high & 2.9 & 1.3 & 1.6 \\
& High & 2.1 & 1.3 & 0.8 \\
EA3 & Low & 4.4 & 1.2 & 3.2 \\
& Mid-low & 2.8 & 1.0 & 1.9 \\
& Mid-high & 2.4 & 1.0 & 1.3 \\
& High & 2.0 & 1.1 & 0.8 \\
EU4 & Low & 4.0 & 1.1 & 2.9 \\
& Midd-low & 2.6 & 0.9 & 1.7 \\
& Mid-high & 2.1 & 0.9 & 1.2 \\
& High & 1.8 & 1.0 & 0.7 \\
\hline
\end{tabular}

Our finding might lend support to the quality signalling proposition of Allen (1988). Since product quality is largely unobservable (before purchase), high price (reflecting high cost) can be used as a signal of high quality in a set-up with repeated interactions between buyers and sellers (or in the presence of some efficient reputation mechanism). Firms feeling concerned about their quality, in considering a price decrease, might fear that their customers will misinterpret the price reduction as a reduction in quality. Given the relevance of price reductions for (most of) the products considered here, quality signalling may impact on the measured frequency of price change. At the same time, one may not exclude that the measured differences with regard to the frequency of price change as a function of the relative price is driven by the outlet structure. For products subject to a downward price trend, mail order companies typically charge relatively high prices the longer the time elapsed since the dissemination of their printed product catalogue.

Moreover, we find substantial variation in the frequency of price change across shops operating in different market environments. Hereafter, market conditions are proxied by the number of competitors for a given product. We distinguish three categories of market environment. Markets characterised by a low number of competitors are considered narrow markets. For our purposes, such markets have their number of competitors lower than the $33^{\text {rd }}$ percentile of the distribution 
of store numbers across all product categories (within one country) ${ }^{17}$. Intermediate markets are characterised by a number of competitors within the interval defined by the $33^{\text {rd }}$ and the $66^{\text {th }}$ percentile of the distribution of the number of shops, while wide markets have more sellers than the $66^{\text {th }}$ percentile.

Table 4: The frequency of price change as a function of the market environment

\begin{tabular}{llccc}
\hline Country & $\begin{array}{c}\text { Type of } \\
\text { market } \\
\text { (proxy) }\end{array}$ & Change & $\begin{array}{c}\text { Frequency of price } \\
\text { Increase }\end{array}$ & Reduction \\
\hline \hline DE & Narrow & 2.1 & 0.8 & 1.3 \\
& Intermediate & 2.9 & 1.1 & 1.9 \\
& Wide & 3.3 & 1.0 & 2.3 \\
FR & Narrow & 2.7 & 1.1 & 1.6 \\
& Intermediate & 3.2 & 1.2 & 2.0 \\
& Wide & 3.5 & 1.2 & 2.3 \\
IT & Narrow & 2.8 & 1.2 & 1.7 \\
& Intermediate & 4.4 & 1.6 & 2.8 \\
& Wide & 4.5 & 1.7 & 2.8 \\
UK & Narrow & 1.5 & 0.6 & 0.9 \\
& Intermediate & 1.7 & 0.6 & 1.0 \\
& Wide & 3.4 & 0.9 & 2.5 \\
US & Narrow & 2.8 & 1.1 & 1.6 \\
& Intermediate & 3.8 & 1.3 & 2.6 \\
& Wide & 1.9 & 0.6 & 1.3 \\
EA3 & Narrow & 2.5 & 1.0 & 1.5 \\
& Intermediate & 3.4 & 1.3 & 2.1 \\
EU4 & Wide & 3.7 & 1.3 & 2.5 \\
& Narrow & 2.2 & 0.9 & 1.3 \\
& Intermediate & 3.0 & 1.1 & 1.9 \\
& Wide & 3.7 & 1.2 & 2.5 \\
\hline
\end{tabular}

Our results suggest that, except for the US, the frequency of price change is lowest in narrow markets (see table 4). Moreover, the frequency of price change typically increases with the number of direct competitors. This holds for all countries except for the US. These results extend to the frequency of price decrease (again with the exception of the US), but not to the frequency of price increase. In interpreting these figures, it is important to note that the number of sellers used in the definition of the market size differs across countries. Whereas in the European countries intermediate markets are characterised by a number of sellers between roughly 8 and 17, intermediate markets in the US are characterised by a minimum number of 20 sellers. Wide markets in the US exhibit 55 sellers at least. In sum, our results indicate that the frequency of price change and of price reduction is not a monotonically increasing function of the number of competitors. Rather, we find that the highest frequencies of price change and of price reduction are obtained in markets with less than 20 , but not too few competitors.

\subsection{Frequency of price change: the role of shipping and handling costs}

In brick-and-mortar stores, the final price for the consumer consists of two components - the price of the item and the consumer-specific transportation costs to the seller. In case of online sellers, the analogy to the transportation cost is the shipping and handling cost. The split of the total price into its two components is a result of each seller's strategic decision. Among online sellers we observe both those who offer free "post-and-package" and others who make their living from the shipping and handling costs that can form a substantial portion of the total price. Hence, the behaviour of the total price may well differ from that of the product price which we considered so far. Since most of the European Internet stores charge flat "post-and-package"

17 As the average number of sellers per product differs substantially across countries, the definition of categories is based on the country-specific distributions of the number of sellers. 
rates and these are quoted on the national Kelkoo sites, we can extend our analysis by considering the total price. Table 5 compares the frequency of price change for a subsample of observations that quote both the product price and the shipping and handling cost.

Table 5: The frequency of price change: Total price versus product price

\begin{tabular}{llccc}
\hline Country & \multicolumn{1}{c}{ Price } & Frequency of price & \\
& & Change & Increase & Reduction \\
\hline \hline DE & Product & 2.7 & 1.0 & 1.8 \\
& Total & 3.0 & 1.1 & 1.9 \\
FR & Product & 3.1 & 1.2 & 1.9 \\
& Total & 4.0 & 1.5 & 2.4 \\
IT & Product & 3.8 & 1.5 & 2.3 \\
& Total & 4.4 & 1.7 & 2.6 \\
UK & Product & 2.1 & 0.7 & 1.4 \\
& Total & 2.3 & 0.8 & 1.5 \\
EA3 & Product & 3.1 & 1.2 & 2.0 \\
& Total & 3.7 & 1.4 & 2.3 \\
EU4 & Product & 2.9 & 1.0 & 1.8 \\
& Total & 3.3 & 1.2 & 2.1 \\
\hline
\end{tabular}

For all four European countries, the frequency of price change is higher when considering the total price rather than the product price. The degree to which modifications to the shipping and handling costs add to the measured price flexibility differs substantially across countries. In the UK, Germany and Italy, the frequency of price change increases by 6 percent, 10 percent and 14 percent, respectively. In France, changes to the shipping and handling costs lead to an almost one percentage point increase in the overall measured daily frequency of price change. In interpreting these results, it is important to note that contrary to the product price, modifications to the shipping and handling costs may stem from qualitative changes. For instance, online retailers may switch from one deliverer to another. Nevertheless, we cannot exclude that some sellers are exploring the demand effects of changes in shipping and handling costs, in particular in Italy and France. This holds because prices of postal services typically change relatively infrequently (for evidence on index data, see Lünnemann and Mathä, 2005a).

\subsection{Duration of price spells}

Additional information on the distribution of the length of price spells capturing duration dependence and time-variant probabilities of price change is provided by the Kaplan-Meier survivor function. For all countries considered, less than 45 percent of all price spells last for a full calendar month or longer (see left hand side panel of figure 5 below). For the four large western European countries, the corresponding ratio is less than 20 percent (France and Italy) or less than 30 percent (Germany and UK).

The right-hand side panel of figure 5 illustrates more conclusively the substantial degree of variation across product categories within a given economy (here illustrated for the case of Germany). For the vast majority of all country-product category cases, at least one half of all price spells fails within one month, which suggests a frequency of price change one may not find in conventional CPI data. At the same time, for some country-product category cases a nonnegligible fraction of prices does not change for relatively long periods of time (say, 70 days), although the costs incurred by the sheer process of changing a price on the web may be insignificant. 
Figure 5: Survivor function by country

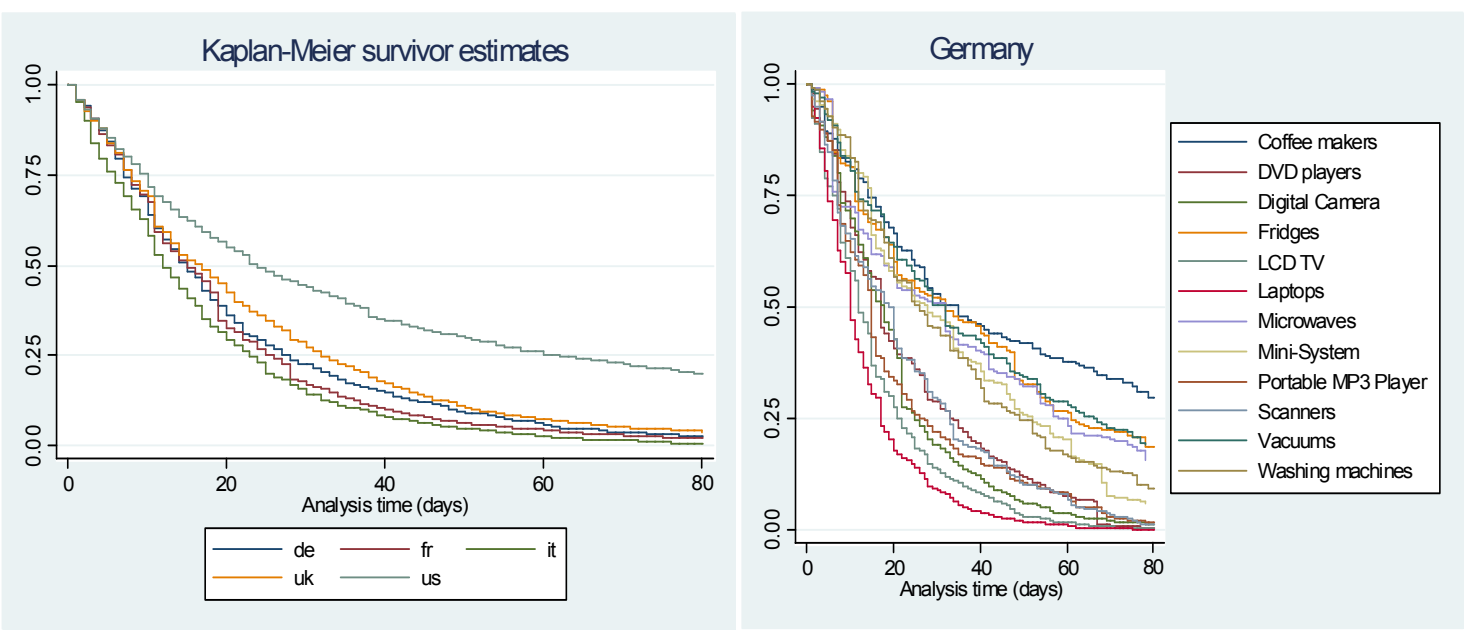

The reasons for the long durations of price spells may be numerous. For example, firms may find reviewing prices more costly than actually changing them, implying that - in an environment offering low costs of price change - the true obstacle to higher price flexibility may be price reviewing rather than price changing. Similarly, very long durations may result from shops offering products not only on the web, but also in brick stores without price differentiation. In particular, mail order companies seem to quote web prices identical to those listed in their catalogues. However, in particular with respect to the product categories considered here, mail order companies typically figure at the upper end of the range of relative prices quoted. With substantial spreads vis-à-vis to their competitors, as the time elapses since the price publication in the catalogue, their offerings become by and large "out of the money" and do not reflect the true degree of price rigidity. Third, firms might choose not to change their prices at too high frequency as the expectations of every day price changes may render potential clients unwilling to buy outright.

In analogy to the summary statistics, our results suggest that the differences across countries are dominated by those observed across product types. Interestingly, the country-specific results are relatively similar with respect to the product types characterised by generally high survivor rates (i.e. small negative slope in figure 5). In all four European countries, coffee makers, mini systems and washing machines reveal relatively moderately sloped survivor functions. For coffee makers, approximately 1 out of 4 price spells prevails after 50 days or longer. At the same time, for all EU4 countries, laptops, LCD TVs, digital cameras and portable MP3 players reveal short price spells. For all four categories, only one out of four price spells (or less even) lasts for a full calendar month. For some categories, such as laptops in France and Germany, the fraction of price spells prevailing after one month is as low as 10 percent approximately.

In addition, we compute hazard rates based on Kaplan-Meier survivor functions. In general, the conclusions from the implied hazard plots are not as evident as in the case of the CPI micro prices. Conventional retail consumer prices are generally characterised by downward sloping hazard plots and mass points around durations of 12 months, 24 months, etc. (see, for example, Dhyne et al, 2005). With Internet prices, hazard plots rarely display a general downward trend over a wide range of durations. Similar to common consumer prices, however, hazard rates for Internet prices reveal mass points at specific durations. For all EU4 countries, we find relatively high hazard rates at a duration of 10 days. In the case of France, Germany and the UK, mass 
points are also observed around durations of 18 to 19 days. In sum, the evidence obtained from hazard rates is much less strong for Internet prices than for common CPI prices.

\subsection{Size of price changes}

Overall, prices change on average by approximately 4.7 percent. Again, the sample structure differs across countries. Assuming an equally weighted distribution of all product categories in all countries considered, the average size of price change is 5.4 percent. At the country level, the equally weighted average price change ranges from 4.5 percent (UK) to 6.8 percent (US). Compared to the CPI studies, the average price change on the Internet is substantially smaller. ${ }^{18}$ The average price change across countries and product categories is 5.2 percent and 5 percent for the EA3 and the EU4, respectively. The larger average price change in the US compared to the EA3 and the EU4 might be the flipside of the lower frequency of price change in the US. ${ }^{19}$ Larger average price change in the US holds for both price reductions and price increases relatively to all EU4 countries. The equally weighted average price increase (decrease) in the US is 7.1 (6.6) percent. The corresponding average increases (decreases) for the EA3 and the EU4 are 4.5 (5.5) percent and 4.5 (5.2) percent, respectively. At the country level and at the product category level, however, there is no clear pattern discernable with regard to the relative size of price increases and price reductions. Nevertheless, we find that in the euro area countries, the average price reduction tends to exceed the average price increase. The opposite applies to two out of three product categories in the US. For all European countries, the average price reduction exceeds the average price increase for five product categories (MP3 players, digital cameras, coffee makers, scanners and microwave ovens). In contrast, we find that the average price reduction is smaller than the average price increase for vacuum cleaners in all countries studied. In line with the findings for brick stores, for almost all product category and country combinations considered, average price changes - whether upward or downward - tend to exceed the annual inflation rates (see, for example, Álvarez et al, 2005).

Apart from product categories, the size of price changes also differs considerably across shop types. As illustrated in figure 6, producers and mail order companies reveal relatively large average price changes, on average 10.4 and 8.6 percent, respectively. Genuine web stores as well as online sellers maintaining a small number of brick-and-mortar shops, on the contrary, implement rather small average price changes ( 4.5 and 4.6 percent, respectively). The average price change for retailers is 6.2 percent.

18 See, for example, Dhyne et al. (2005). They report an average price increase (decrease) by 8.2 (10) percent.

19 Notice that this is not the case with common CPI data. Dhyne et al. (2005) report smaller frequencies of price change and smaller average price changes for the euro area countries than it is the case in the US. 


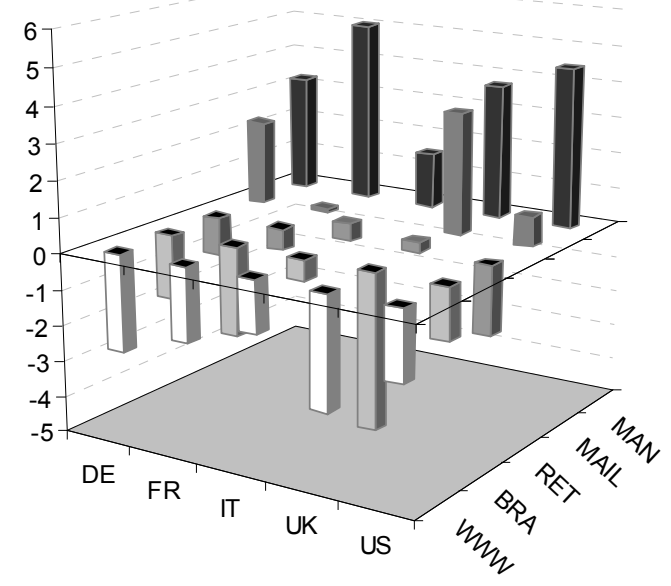

Remark: For the purpose of illustration, the average size of price change by shop type figures as a difference from the country average. www, bra, ret, man and mail characterise genuine online stores, online stores with few branches, stores with numerous highstreet stores, manufacturers and mail order companies, respectively.

Although the distribution of the size of price changes displays strong skewness in all countries (see figure 7 below) and for all product categories considered, the above findings extend to the median size of price changes. Again, both price increases and price reductions tend to be larger in the US than in the EU4. However, the median price changes are considerably smaller than average size changes. Across all countries and product categories, the average price increase (price reduction) is approximately 5.0 (5.5) percent, while the median price increase (decrease) is 2.9 (3.1) percent. Similar to the findings from micro CPI studies, the average size of a price change is affected by a smaller number of very sizeable price changes.

In all countries, tiny price changes (say, 1 percent and smaller) occur relatively often. For all countries, more than two out of ten price changes do not exceed one percent in absolute terms. As already indicated in section 3.1, negative price changes occur more frequently than price increases. Moreover, for all countries (except for Italy) the price change interval $[-1,0)$ percent contains the largest number of price changes. The predominance of very small price changes reveals a marked difference with regard to common CPI prices, where very small price changes are much less prominent (Hoffmann and Kurz-Kim, 2006). This may relate to the smaller costs involved in actually changing prices on the web compared to reprinting and delivering new price tags for conventional high street stores. Figure 7 below also documents that, in spite of the similar costs incurred by the mere process of changing prices on the web, the distribution of price changes differs substantially across countries. In particular, we find a distribution much more concentrated around very small price changes in the UK, but also in Germany and the US. In these countries, the share of price changes in the interval $[-1,0)$ is 20 percent or more. On the other hand, the distribution of price changes is less concentrated around zero and has lower kurtosis in France and Italy. In particular in Italy, the fraction of price changes in the interval $[-1,0)$ is only 11 percent. 
Figure 7: The distribution of the size of price changes (EU4 countries)
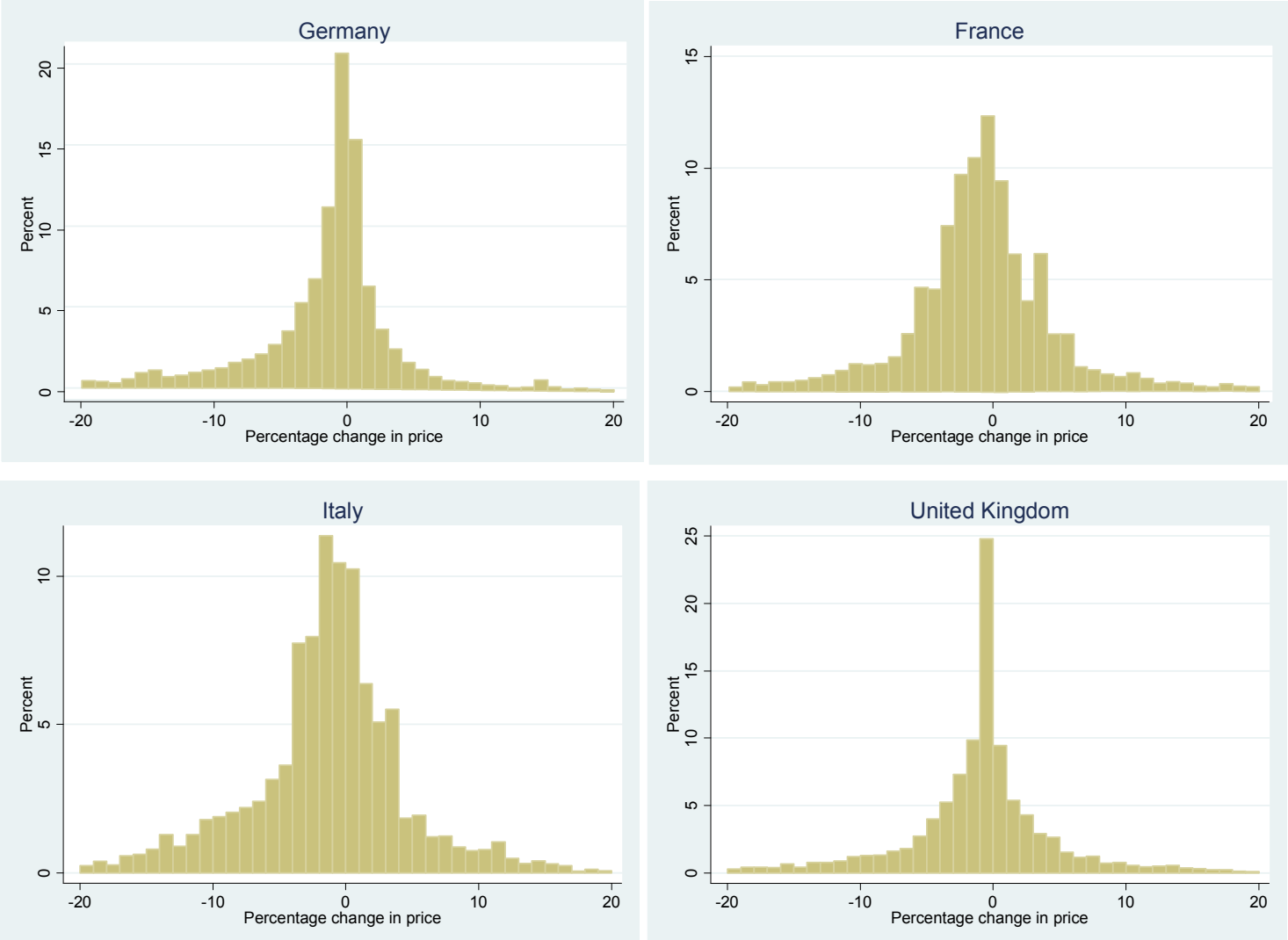

The observed differences in the distribution of price changes suggest that the interplay of the frequency of price change and the size of such changes may vary. Given a similar trend in the level of prices, high frequencies of price change in combination with relatively large average price changes (as for example in Italy) may imply a tendency of price changes to revert. Evidence from CPI micro studies suggests that price reversions can account for a considerable fraction of total price changes (see, for example, Lünnemann and Mathä, 2005b). Reversion of price changes typically occurs during temporary promotions and end-of-season sales, which, in turn, are particularly common for food items and non-energy industrial goods (see, for example, Warner and Barsky, 1995). From a monetary policy perspective, price changes due to reasons other than a comprehensive price review are of limited interest. Measures of price flexibility including price reversions may hence be driven by changes of purely seasonal nature and may say little about the true cost of price adjustment.

With regard to Internet prices, across all countries and product types considered, we observe almost 19 percent less price changes when ignoring price changes that become reverted afterwards. ${ }^{20}$ Price change reversals are least common in the UK, where they represent 12 percent of all price changes. The other extreme is Italy where price changes that become reverted afterwards account for almost 26 percent of total price changes. The cross-country differences with regard to the distribution of the size of price changes (see figure 7 above), thus, have to be interpreted accordingly. Similarly to CPI prices, the sheer number of reverted Internet price changes may overstate the true degree of price flexibility, albeit to a smaller extent relative to the headline frequency of price change.

20 Due to data limitations, in the following, a price change reversal is considered a price increase (price reduction) that is reverted by a subsequent equal size price reduction (increase), irrespective of the 
Table 6: The frequency of price change: the impact of price change reversion

\begin{tabular}{|c|c|c|c|c|c|c|c|c|}
\hline & & DE & FR & IT & UK & US & EA3 & EU4 \\
\hline Total & [\%] & 2.7 & 3.1 & 3.8 & 2.1 & 2.5 & 3.1 & 2.9 \\
\hline \multicolumn{9}{|c|}{ of which due to price change reversion: } \\
\hline & [\% pts] & 0.4 & 0.5 & 1.0 & 0.3 & 0.5 & 0.6 & 0.5 \\
\hline \multicolumn{9}{|c|}{ Frequency of price change reversion as a share of total frequency of price change: } \\
\hline & [\%] & 13.9 & 16.1 & 25.6 & 12.0 & 21.5 & 17.9 & 16.4 \\
\hline
\end{tabular}

\subsection{Internet versus brick stores}

At this stage, a direct comparison of the degree of price stickiness between brick stores and Internet sellers is hardly feasible because it is difficult to obtain micro price data for perfectly comparable product categories. Whereas the range of products sold online is still fairly narrow (in particular in the European countries), corresponding CPI data are difficult to obtain because of their confidential nature. In addition, due to administrative burden and institutional delays, even recent studies on micro CPI prices can hardly provide results for the period considered here. For this reason, all comparisons derived below are made under the, admittedly strong, assumption of no time variation in the behaviour of consumer prices. The 50-product sample examined in Italy by Veronese et al. (2005) does not entail items equivalent to those studied here. Whereas the analysis by Baudry et al. (2004) includes an extensive range of products, the precise items incorporated in the French CPI are confidential. Hoffmann and Kurz-Kim (2006), based on their micro CPI data set for Germany, report that the frequency of price change for TV sets, HiFi systems and toasters ${ }^{21}$ is $7.1,5$ and 3.9 percent, respectively. As these frequencies are expressed in monthly terms, the implied median durations exceed a period of 9 months. These compare to implied median durations of Internet price spells of approximately 66,48 and 15 days for coffee makers, mini-systems and LCD TVs, respectively (see figure 8 below). ${ }^{22}$ Notice that the ranking of these three categories is the same in both brick and Internet stores. For the three categories considered here, both Internet prices and brick store prices change more frequently downward than upward. The share of downward adjustments in total changes is approximately 66 (76) percent for HiFi systems, 72 (73) percent for TV sets and 57 (54) percent for coffee makers/toasters (brick stores in parentheses). According to Hoffmann and Kurz-Kim (2006), CPI prices rise/decline on average by roughly 8.4/11.7 percent for HiFi system, 8.9/10.6 percent for TV sets and 6.9/10.4 percent for toasters. The average changes in Internet prices are less sizeable (3.8/6.8, 3.7/5.7 and 7.1/8.6 percent, respectively). However, one has to bear in mind that the frequency of price change is much higher on the Internet. The observation that price reductions are larger than price increases is in line with the findings of CPI studies.

time elapsed. Obviously, this definition yields a lower bound of the true frequency of price change reversals.

21 For the purpose of this exercise, toasters are considered broadly comparable to coffee makers. The figures by Hoffmann and Kurz-Kim (2006) cited here refer to the frequency of price change obtained when considering matched models only. This is because in examining Internet prices we do not consider replacements (whether quality adjusted or not).

22 Note that due to the different frequencies of price collection, the implied duration is not perfectly comparable between the two sets of products. 
Figure 8: Implied median durations of price spells: Internet prices versus CPI prices
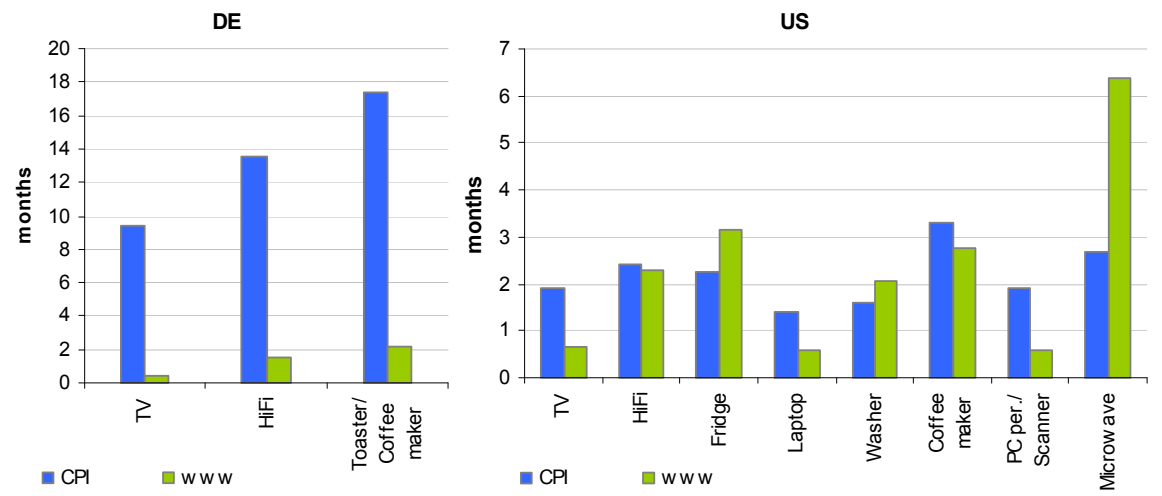

Remark: Implied durations not perfectly comparable due to different frequencies of data collection. Sources: Bils and Klenow (2004), Hoffmann and Kurz-Kim (2006), own calculations.

Based on the results obtained by Bils and Klenow (2004) using the BLS price quotes, we can distinguish two broad groups of product categories in the US. For mini-systems, the implied median duration in Internet stores is broadly similar to those for prices collected in brick stores (2.4 months compared to 2.3 months for HiFi systems). TV sets, laptops and scanners reveal longer duration of price spells in brick stores $(1.9,1.4$ and 1.9 months, respectively) than on the Internet $(0.7,0.6$ and 0.6 months, respectively). In contrast, washing machines, fridges and microwaves exhibit longer implied durations on the Internet $(2.1,3.2$ and 6.4 months, respectively) than in traditional brick-and-mortar shops (1.6, 2.3 and 2.7 months, respectively). Overall, Internet prices in Germany reveal much smaller degree of price stickiness than brick store prices, whereas in the US Internet prices are not necessarily less sticky than micro CPI prices.

For photo development services, over a 4-month download period, we recorded a mere 14 price changes (out of which 11 took place in the UK). In our sample, the overall daily frequency of price change for photo development was approximately 0.12 percent, leading to an implied average frequency of price change well in excess of a full calendar year. Of course, given the very small number of price changes actually recorded, these numbers have to be interpreted with caution. In addition, the download period did not cover the month of January, a month typically characterized by relatively frequent price adjustments for services. Among others, Dhyne et al. (2005) report an average monthly frequency of price change for photo development within the euro area of 3.6 percent, also implying an average price spell duration of more than 1 year.

In sum, the general idea of a substantially higher degree of price stickiness in the euro area countries as compared to the US is not backed by Internet prices. In addition, in all countries considered, a substantial proportion of Internet price spells fails within a single calendar month, thereby implying a frequency of price change that CPI studies typically fail to capture. Hence, given the high penetration rate of Internet access and the increasing importance of consumer purchases on the web, the relatively low frequency of price adjustment observed in the CPI prices bears the risk of (increasingly) overstating the true degree of rigidity of consumer prices in the euro area countries. In case of services, however, it seems that the Internet does not necessarily lead to a substantial increase in the frequency of price changes relative to common highstreet outlets. The above findings, thus, indicate that e-retailing may promote the flexibility of consumer prices for consumer goods in an environment of low price flexibility in traditional retailing. In contrast, the Internet prices of consumer services do not seem to be more flexible. 
This, in turn, may indicate that prices of consumer services are "inherently" sticky, whereas those of consumer goods are not, and that the traditional retail sector adds stickiness to otherwise relatively flexible prices.

\subsection{Comparison of identical models}

So far, cross-country comparisons of consumer price behaviour typically focused on broad product types and/or a sample of elementary products (see, for example, Dhyne et al., 2005). However, due to assumed differences in consumer preferences, technical standards, etc., price quotes collected by national statistical institutes as well as those downloaded from the Internet, relate to different models. Cross-country comparisons rarely take account of such differences. Although this paper deals with a narrow set of consumer product categories, the products considered are not necessarily identical. In order to circumvent differences in the degree of price stickiness due to differences in the composition of the country-specific baskets considered, we identify a set of identical models listed in all 5 countries. The matching procedure was applied to digital cameras only. Overall, 39 identical models were identified which, in turn, were listed by 345 shops.

Table 7: Frequency of price change (identical models)

\begin{tabular}{lccccccc}
\hline \hline & DE & FR & IT & UK & US & EA3 & EU4 \\
\hline \hline Total & 3.1 & 5.9 & 5.1 & 5.0 & 5.3 & 4.5 & 4.6 \\
Across models: & & & & & & & \\
$\quad$ Price change & 3.2 & 5.9 & 5.1 & 5.0 & 4.9 & 4.5 & 4.7 \\
$\quad$ Price increase & 0.7 & 1.6 & 2.0 & 1.7 & 1.3 & 1.3 & 1.4 \\
$\quad$ Price reduction & 2.5 & 4.3 & 3.1 & 3.3 & 3.6 & 3.2 & 3.2 \\
By shop type: & & & & & & & \\
$\quad$ WWW & 3.5 & 8.0 & 6.3 & 5.3 & 6.4 & 5.7 & 5.6 \\
$\quad$ BRA & 1.9 & 2.7 & 1.4 & 4.2 & 3.6 & 2.0 & 2.5 \\
$\quad$ RET & 4.1 & 4.2 & 1.6 & 2.1 & 4.9 & 3.4 & 3.1 \\
$\quad$ MAN & 0.7 & 3.0 & 8.3 & 2.1 & 7.0 & 3.5 & 3.2 \\
$\quad$ MAIL & 0.4 & 2.6 & & 0.0 & 2.2 & 1.3 & 0.9 \\
By relative price level: & & & & & & & \\
$\quad$ LOW & 6.3 & 10.0 & 10.2 & 11.3 & 10.4 & 8.5 & 9.2 \\
$\quad$ MID-LOW & 2.4 & 3.7 & 3.9 & 5.0 & 5.2 & 3.2 & 3.7 \\
$\quad$ MID-HIGH & 1.6 & 2.2 & 2.8 & 2.6 & 3.6 & 2.1 & 2.2 \\
$\quad$ HIGH & 1.4 & 2.4 & 2.2 & 2.3 & 2.1 & 1.9 & 2.0 \\
\hline \hline
\end{tabular}

Remark: www, bra, ret, man and mail characterise genuine online stores, online stores with few branches, stores with numerous highstreet stores, manufacturers and mail order companies, respectively.

Across all countries and models, the average frequency of price change is 4.9 percent. Our results suggest considerable variation in the price behaviour across countries even in this small selection of identical products. Whereas in France, the average frequency of price change reaches 5.9 percent, the corresponding figure for Germany is 3.1 percent. Across the entire distribution, the frequency of price change is relatively low in Germany. At the same time, on average across all models, price changes are largest in Germany (5.7 percent), whereas in the remaining countries the average price change is from 3.5 percent (Italy) to 4.5 percent (US). In addition, with regard to the frequency of price change, the discrepancies between models are fairly limited in Germany, whereas in France in particular a wide range of frequencies is observed across the 39 models considered. Even at this fairly narrow product level, within any given country, the spread observed across models exceeds the average differences across countries. 
The frequency of price change varies substantially across shop types. We find relatively high frequencies of price change for genuine online stores. Whereas for all countries the lowest frequency of price change is obtained for mail order firms, in general, no unique ranking is obtained across all countries considered. Again, shops charging very competitive prices reveal a relatively high frequency of price change (approximately 9.7 percent for the full sample), whereas high price shops reveal a relatively small frequency of price change (2.0 percent for the full sample). For all five countries we find that the higher the relative price level, the lower the frequency of price change.

\subsection{Out-of-stock versus in-stock products}

Based on their analysis of supermarket prices in Buenos Aires, Burstein et al. (2005) find that the frequency of price change for a given product can be also affected by its terms of availability. ${ }^{23}$ The information on availability status was provided only in the US. ${ }^{24}$ Overall, we find a substantially different behaviour for in-stock items on one hand and out-of-stock items on the other hand. First, firms not only change prices of products in stock, but also those of out-ofstock products. However, in-stock items are much more frequently subject to price changes than out-of-stock items. Whereas the frequency of price change for in-stock items is approximately 3.9 percent, the corresponding figure for out-of-stock items is 1.1 percent only. Second, relative to the overall frequency of price change, prices for out-of-stock items fall less often. Whereas price reductions represent two out of three price changes for in-stock items, the share of price reductions in total price changes is only slightly more than 50 percent for out-of-stock items. ${ }^{25}$ Third, price changes tend to be larger for out-of-stock items. More specifically, the average price change for out-of-stock items (9.1 percent) is more than double the size of the average price change for in-stock items (4.5 percent). The difference with regard to the size of the price change becomes even more pronounced at their median levels $(2.0$ and 5.5 percent, respectively). The size spread relates to both price increases and price decreases.

\section{On the determinants of the probability of a price change}

\subsection{Model}

This section investigates the determinants of the likelihood of observing a price change. Following Cecchetti (1986), the likelihood of observing a price change between period $t$ and $t+1$ is modelled by means of a logit model. For that purpose, we define a dichotomous variable $y_{i j t}$ indicating whether the price of product $i$ in store $j\left(p_{i j t}\right)$ has changed $(=1)$ between time $t$ and $t+1$ or not $(=0)$. Formally,

$$
y_{i j t}=\left\{\begin{array}{l}
1 \text { if } p_{i j t+1} \neq p_{i j t} \\
0 \text { otherwise }
\end{array} .\right.
$$

The model specifying the likelihood of observing a price change between $t$ and $t+1$ is given by

23 More specifically, they report that most price adjustments occur after a stock-out. They find that the probability of a price change, conditional on the good not being on the shelf on the previous day, is one third.

24 Note that this distinction, in general, is ignored when studying individual CPI prices given the way unavailable products are treated by national statistical institutes.

25 Of course, one cannot exclude any bias in both figures as the in-stock information provided by the sellers may be a poor indicator of product availability. To the extent that online outlets tend to overestimate the availability of their products, the true frequency of price change for in-stock products would be higher than the measured frequency of price change thereby widening the gap between products in stock and out-of-stock products. 


$$
\begin{aligned}
& \operatorname{Prob}\left[y_{i j t}=1\right]=\frac{\exp \left(X_{i j t} \beta+u_{i}+\varepsilon_{i j t}\right)}{1+\exp \left(X_{i j t} \beta+u_{i}+\varepsilon_{i j t}\right)} \text {, where } \\
& \begin{aligned}
X_{i j t} \beta= & \delta_{0}+\delta_{1} \ln \left(\operatorname{len}_{i j, t-T}\right)+\delta_{2} \operatorname{dur}_{i j t}+\delta_{3} \text { Mon }_{t}+\delta_{4} \text { Tue }_{t}+\delta_{5} \text { Wed }_{t}+\delta_{6} \text { Thu }_{t}+\delta_{7} \text { Fri }_{t}+\delta_{8} \text { Sat }_{t} \\
& +\chi_{1} \text { attr }_{i j t}+\chi_{2} \text { sel }_{i t}+\chi_{3} \text { rat }_{j}+\chi_{4} \text { numprod }_{i j t}+\chi_{5} \text { pctpchg }_{i t}+\chi_{6} \text { mpchg }_{i t} \\
& +\sum_{q=2}^{4} \lambda_{q} \text { rank }_{q, i j t}+\sum_{p=2}^{8} \kappa_{p} \text { prod }_{p, i}+\sum_{c=2}^{5} \mu_{c} \text { country }_{c, i j t}+\sum_{s=2}^{6} \theta_{s} \text { shoptype }_{s, j}
\end{aligned}
\end{aligned}
$$

where $\varepsilon_{i j t}$ and $u_{i}$ denote the independently distributed error term and the random effect specific to the product category, respectively. ${ }^{26}$

Following recent studies on the determinants of price change (see, for example, Aucremanne and Dhyne, 2004), the above specification allows for both time-dependent and state-dependent factors in the determination of price changes. Among the state dependent factors we distinguish "attractive" prices $\left(a_{t t r i j t}\right)$, the number of sellers offering the particular item $\left(\operatorname{sel}_{i t}\right)$, the outlet's relative ranking within the distribution of product $i$ 's price $\left(r a n k_{q, j i t}\right)$ and the merchant's rating $\left(r a t_{j}\right)$. In addition, we consider the number of products a given seller is offering within a specific product category $\left(\operatorname{numprod}_{i j t}\right)$. The specification also captures the fraction of price quotes of a particular product that changed on the previous day $\left(\right.$ pctpch $\left._{i t}\right)$ and includes an indicator showing whether the minimum price of a given product changed on the previous day ( $m p c h g_{i t}$ ). Finally, we include a dummy variable for each day of the week ( $\mathrm{Mon}_{t}$ to $\left.\mathrm{Sat}_{t}\right)$, as well as shop type ( shoptype $\left._{s}\right)$, country $\left(\right.$ country $\left._{c}\right)$ and product category identifiers $\left(\operatorname{prod}_{p}\right)$.

Within the context of identical products, we also consider two variants of model (1) that focus separately on price decreases and price increases. For this reason, we define additional variables $y_{i j t}^{+}\left(y_{i j t}^{-}\right)$as binary variables indicating whether, for a given product, the price $p_{i j t}$ has increased (decreased) between time $t$ and $t+1$ or not,

$$
y_{i j t}^{+}=\left\{\begin{array}{l}
1 \text { if } p_{i j t+1}>p_{i j t} \\
0 \text { otherwise }
\end{array}, \quad y_{i j t}^{-}=\left\{\begin{array}{l}
1 \text { if } p_{i j t+1}<p_{i j t} \\
0 \text { otherwise }
\end{array} .\right.\right.
$$

The modified model for price increases takes the following form

$$
\begin{aligned}
\operatorname{Prob}\left[y_{i j t}^{+}\right. & =1]=\frac{\exp \left(X_{i j t}^{+} \beta+u_{i}^{+}+\varepsilon_{i j t}^{+}\right)}{1+\exp \left(X_{i j t}^{+} \beta+u_{i}^{+}+\varepsilon_{i j t}^{+}\right)} \text {, where } \\
X_{i j t}^{+} \beta & =\delta_{0}+\delta_{1} \ln \left(\operatorname{len}_{i j, t-T}\right)+\delta_{2} \operatorname{dur}_{i j t}+\delta_{3} \text { Mon }_{t}+\delta_{4} \text { Tue }_{t}+\delta_{5} \text { Wed }_{t}+\delta_{6} \text { Thu }_{t}+\delta_{7} \text { Fri }_{t} \\
& +\chi_{1} \text { attr }_{i j t}+\chi_{2} \text { sel }_{i t}+\chi_{4} \text { numprod }_{i j t}+\gamma_{1} l_{-} \text {pup }_{-} \text {size }_{i j t}+\gamma_{2} l_{-} \text {pdo_size } \\
& +\chi_{i j t}+\gamma_{3} l_{-} p c d o_{i j t} \\
& +\chi_{5} \text { pctpup }_{i t}+\chi_{6} \text { mpup }_{i t}+\sum_{q=2}^{4} \lambda_{q} \text { rank }_{q, i j t}+\sum_{c=2}^{5} \mu_{c} \text { country }_{c, i j t}+\sum_{s=2}^{6} \theta_{s} \text { shoptype }_{s, j}
\end{aligned}
$$

where $\varepsilon_{i j t}^{+}$and $u_{i}^{+}$denote as before the independently distributed error term and the random effect specific to the product category, respectively.

The model for price decreases is a straightforward modification of model (2) using the definition of $y_{i j t}^{-}$. In model (2), special attention is given to the characteristics of the preceding price change. The size of the preceding price increase (price reduction) is captured by $l_{-}$pup_size $e_{i j t}$ $\left(l_{-} p d o_{-}\right.$size $\left._{i j t}\right) \cdot l_{-} p c d o_{i j t}$ is a dummy variable indicating whether the preceding price change

26 Note that not all variables are available for all countries. For example, the seller's rating is available in the US only. 
led to a price reduction. pctpup $_{i t}\left(\right.$ pctpdo $\left._{i t}\right)$ and mpup $_{i t}\left(m p d o_{i t}\right)$ correspond to the variables pctpchg $_{i t}$ and $m p c h g_{i t}$ but relate only to price increases (price reductions).

The variable $a t t r_{i j t}$ is an indicator of attractive prices (such as $\$ 9.99$ or $€ 29$ or $£ 0.99$ ). In theory, such prices may convey information well beyond the sheer price level. The analysis of micro CPI prices suggests that attractive prices are very common in traditional retailing. The existence of pricing thresholds is expected to reduce the likelihood of a price change within a given period of time as firms are supposed to change prices only if an alternative pricing point is reached (see, for example, Dhyne et al., 2005).

The number of shops listing a given model on a given day on the particular price comparison site is captured by the $\operatorname{sel}_{i t}$ variable. Though this is a lower bound to the number of competitors, it reflects the immediate choice of the consumer attainable with a mouse click.

$\operatorname{rank}_{q, j i t}$ is a proxy for the competitiveness of the price of product $i$ in shop $j$ at time $t$ relative to its competitors. Due to differences in the number of the sellers across products, the competitiveness of a price in a given shop $j$ is defined in terms of percentiles, rather than the ranking in absolute numbers. A price in shop $j$ for product $i$ at time $t$ is considered (particularly) competitive as long as it lies within the $25^{\text {th }}$ percentile of the distribution of prices for product $i$ at that date (captured by dummy variable "low"). The remainder of price quotes is divided into "midlow" (i.e. $\left.\left.p_{i j t} \in\right] p_{i t}^{q 1}, p_{i t}^{q 2}\right]$ ), "mid-high" (i.e. $\left.\left.p_{i j t} \in\right] p_{i t}^{q 2}, p_{i t}^{q 3}\right]$ ), and "high" (i.e. $\left.\left.p_{i j t} \in\right] p_{i t}^{q 3}, p_{i t}^{q 4}\right]$ ) categories, where $q x$ denotes the $x^{\text {th }}$ quartile of the price distribution at time $t(\forall x \in[1,2,3,4])$.

Information on the rating of a shop $\mathrm{rat}_{j}$ is calculated from the assessments provided by customers online during and after selected transactions. This variable is available only in the US and only for a subset of shops because a minimum number of customer surveys during the last 90 days are required. The rating of any given shop can range from 0 (no consumer satisfaction) to 10 (highest consumer satisfaction). ${ }^{27}$ Obviously, one cannot rule out a bias in this measure. shoptype $_{j}$ characterises the type of shop j according to the five categories used in section 2 of this paper.

The variable numprod $_{i j t}$ reflects the size and the visibility of an Internet outlet. Of course, the number of products offered can only be a rough proxy for the size of an outlet or its market share. $^{28}$ pctpchg $_{i t}$ characterises the percentage share of price quotes for a particular product that changed yesterday. It is meant to serve as a rough indicator of possible interaction effects between sellers when deciding on price changes. The assumption is that, for a given outlet, the more price quotes changed yesterday, the higher the likelihood of a price change today. $m p c h g_{\text {it }}$ indicates whether, for a given product, the minimum price changed over the last three days. Again, the hypothesis is that a change to the minimum price incites shops to follow suit.

$\ln \left(\operatorname{len}_{i, t, t-T}\right)$ is the log duration of a price spell for product $i$ in shop $j$ at price level $p_{i j t}$ since its beginning in $T$. Analyses of price behaviour at the micro level typically suggest a downward sloping aggregate hazard rate (Dhyne et al, 2005), which seem to be at odds with standard theoretical models of price setting (e.g. Calvo, Taylor). Álvarez et al. (2005b) show that unconditional aggregate decreasing hazards are not necessarily evidence against the use of

\footnotetext{
27 The process used to calculate the merchant's rating on www.bizrate.com is described at http://www.bizrate.com/content/ratings_guide.html\#10

28 The count of products reckons only those that we monitored.
} 
standard pricing models, but rather may be due to the aggregation of heterogeneous price setters.

$d u r 7_{i j t}$ captures further time-dependent factors affecting the frequency of price change. Similarly to conventional CPI micro price studies employing specific dummies for durations of 1 month, 6 months, 12 months and 24 months (see, for example, Baumgartner et al., 2005), we use a dummy at duration length of 7 days to account for the potential presence of sellers changing their prices with weekly or bi-weekly frequency. In most cases, however, the dummy at duration of 7 days turned out most relevant. ${ }^{29}$

Weekday dummies $\mathrm{Mon}_{t}$ to $\mathrm{Sat}_{t}$ are intended to capture intra-week effects with respect to the likelihood of observing a price change between $t$ and $t+1$. Similarly, we include dummy variables for each product category $p$, seller type $s$ and country $c$ in order to account for otherwise uncontrolled product-specific fixed effects and country differences.

\subsection{Results across all product categories}

Estimates of model (1) given in table 8 are based on a 25-percent sample of all relevant observations. We adopted random sampling of price spells with the condition that the proportion of each product category (and country) is maintained in the sample. Similarly to the findings from recent CPI micro studies (see, for example, Álvarez et al., 2005), our panel logit estimates suggest that the likelihood of observing a price change is affected by both state- and timedependent factors.

The first column of table 8 presents the estimated odds ratios for model (1) based on the data from Bizrate. We find a significant coefficient on the log-duration of a price spell implying that the longer the duration of the price spell, the lower the odds of observing a price change. This result is often obtained when analysing conventional CPI micro prices (see e.g. Aucremanne and Dhyne, 2005). As already indicated, the negative slope may be due to heterogeneity not accounted for by the specification at hand. Interestingly, the heterogeneity seems to persist even within the very narrow product categories considered here. In their study of U.S. scanner data, Campbell and Eden (2005) find that the probability of a nominal adjustment declines with the time elapsed since the last price change. However, they suggest that the time dependence does not merely reflect heterogeneity in price flexibility across products and stores, but arises rather from "occasional spells of flexibility punctuating otherwise rigid prices".

As already suggested in section 3.5, the evidence with regard to the role of specific duration thresholds is opaque. Contrary to the analysis of conventional CPI micro prices, we do not find any consistently significant role of specific time dummies, such as 1 day, 1 week, 2 weeks, etc. Whereas in conventional CPI micro studies, the one month duration property reveals a significant impact on the likelihood of a price change, the same does not apply to the one day dummy variable in our model. Nevertheless, this is related to the use of separate weekday dummies in our specification. Contrary to the duration dummies, we find that the likelihood of a price change is significantly affected by the day of the week on which the price quote was collected. In the US, the odds of observing a price change are smallest on Sundays. In contrast, the likelihood of a price change is relatively high on Thursdays, Tuesdays and Fridays (in descending order). More specifically, our results suggest that ceteris paribus the odds of a price change on Thursdays are five times as high as on Sundays. For the EU4, the likelihood of a price change on Saturdays is significantly smaller than on any other workday. Price changes

29 As Kelkoo does not allow for price changes on Sunday, for the EU4 specification, a dummy at duration length 6 is used instead. 
have highest likelihood on Tuesdays while Mondays, Wednesdays and Thursdays share similar likelihoods of price change, other things equal.

What concerns the state-dependent factors, a number of variables is found to affect the likelihood of a price change. In line with the conventional CPI micro price studies (Dhyne et al., 2005), prices set at "attractive" levels reveal smaller likelihood of a price change. More specifically, the odds of a price change are reduced by 23 percent (EU4) to 31 percent (US), all else equal. For both the US and the EU4, the likelihood of a price change is also significantly affected by the number of sellers offering the product so that the larger the number of sellers, the higher the odds of a price change. This might reflect a higher degree of perceived competition (on the role of perceived competition, see, for example, Fabiani et al., 2005) or effective competition (on the role of competition for the degree of price flexibility, see, for example, Álvarez et al., 2005c). As suggested by the summary statistics, the odds of a price change depend on the relative price level of a given price quote on a particular day. In both the US and the EU4, the likelihood of a price change is significantly lower for outlets asking prices exceeding the $25^{\text {th }}$ percentile relative to those outlets offering very competitive prices (that is priced below the $25^{\text {th }}$ percentile threshold). Note that this finding is stronger than the one obtained in section 4.2 as the logit model accounts for differences in the frequency of price change across shop types and product types. As already mentioned, this result might lend support to the quality signalling proposition of Allen (1988).

Furthermore, the likelihood of a price change is significantly influenced by the shop type. The results in table 8 below suggest that for both the US and the EU4 Internet based outlets maintaining at most two brick stores (pick-up points or showrooms) have significantly lower odds of a price change than stores selling exclusively through the web. Particularly small likelihoods of price changes are obtained for mail order companies in both samples. For a mail order company, the odds of a price change decline ceteris paribus by 39 percent in the US and 67 percent in the EU4 relative to genuine web outlets. In the US, the smallest likelihood of a price change is obtained for sellers offering their products primarily through TV or home shopping, implying a reduction by more than 60 percent. Although the coefficient is statistically significant, this finding has to be interpreted with caution as the number of observations in this category is relatively small. Whereas in the US, retailers offering online shopping facilities reveal a significantly higher likelihood of price change compared to pure web outlets, the contrary applies to the EU4 where the odds of a price change are reduced by almost 30 percent when compared to the genuine web stores. Another attribute characterising the outlet is its rating. The results suggest that the merchant's ranking has a significant impact on the likelihood of a price change in the US. ${ }^{30}$ An improvement in the shop rating by 1 point (on the 0 to 10 scale) increases the odds of a price change by 14 percent. As the calculation of the ranking number is based on customer surveys that do not ask about frequency of price changes, we can conclude that shops with higher level of customer satisfaction change their prices more often, all other things equal. The last attribute of a shop entering the model is the number of products offered within each product category. In this case we cannot conclude as the variable is statistically insignificant in both samples.

In model (1) we also test for the interaction effects between sellers. Table 8 illustrates that, for a given product, the percentage share of sellers that changed their price of a particular product on the previous day has a significant impact on the likelihood of a price change on the following day. Interestingly, the predicted effect has the same magnitude in both the US and EU4. More specifically, one percentage point increase in the fraction of prices that changed yesterday raises the odds of a price change today by approximately 0.6 percent. In contrast, our results do

30 Note that information on the shop rating is available for the US only. 
not unanimously lend support to the hypothesis that the likelihood of a price change is significantly increased by a change in the minimum price of the product on the previous day. This prediction holds for the US, but in the EU4 we do not find a significant effect of the indicator of a minimum price change on the previous day on the likelihood of a price change.

Table 8: Panel logit estimates of the likelihood of price change (odds ratios)

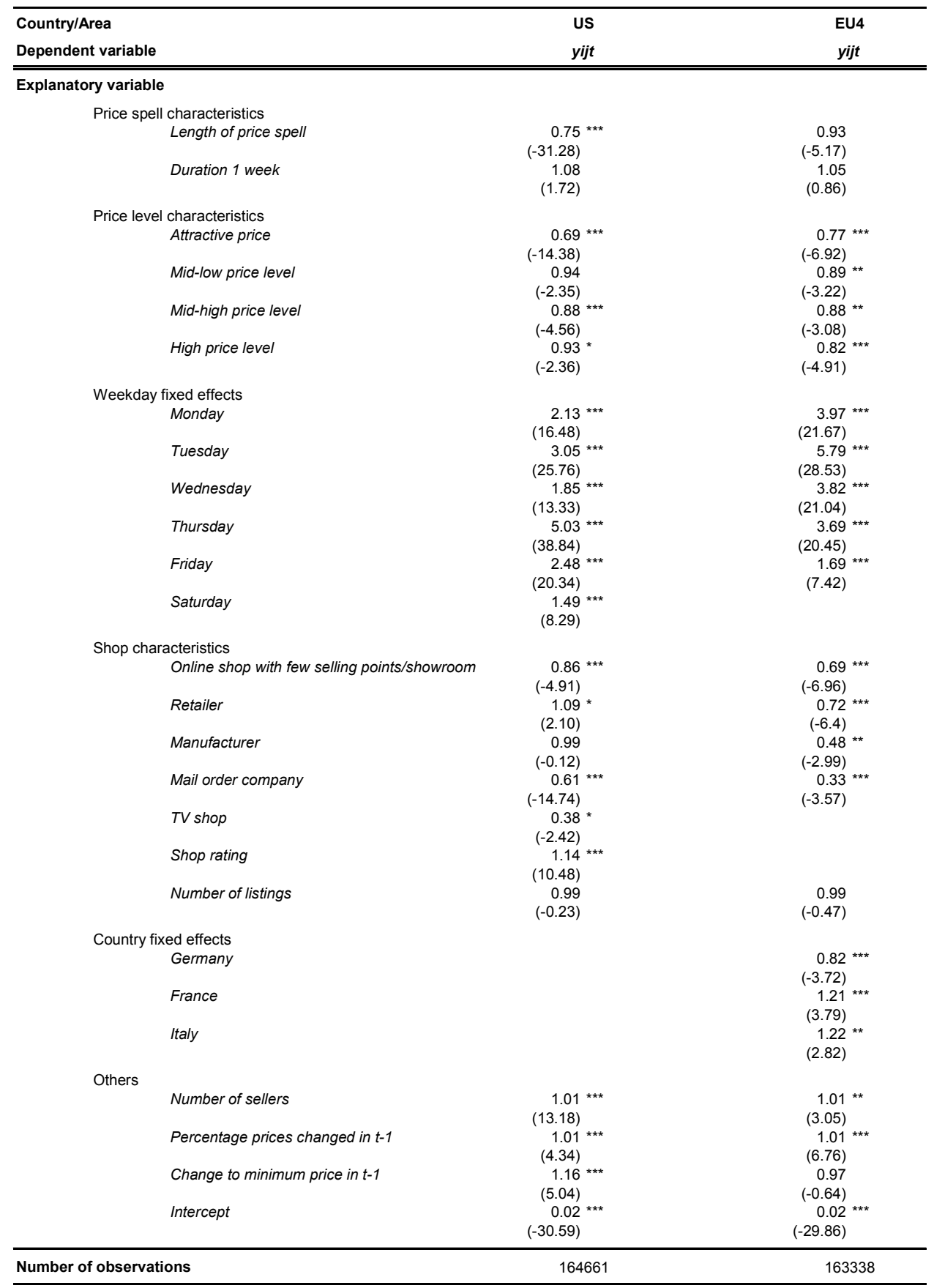

Note: The table lists odds ratios, $\mathrm{Z}$-statistics in parentheses. ${ }^{* / * / * * *}$ indicate significance at the 5/1/0.1 percent level, respectively. Results for US relative to Sunday/DVD players. Results for EU4 relative to Saturday/DVD players/UK. Product category identifiers not illustrated. 
To explore potential differences between the individual EU4 countries, we extend model (1) by a set of country-specific interaction dummies for each explanatory variable. In the next step we exclude all insignificant interaction dummy variables and re-estimate the model. Based on the results presented in table $A 1$ in Appendix $A$ and joint significance tests (using 5\% significance level), we conclude that there are no significant differences across the four European countries in the effects of the following variables on the likelihood of a price change: duration of one week, attractive prices, all relative price indicators and manufacturer and mail order company indicators. We have found that the effect of the log-duration of a price spell is not statistically distinguishable in Italy and France on one hand and in the UK and Germany on the other hand. In France and Italy the effect is significantly positive while in the UK and Germany significantly negative. The effect of one additional seller is significant and positive in Germany and France but it is insignificant in the remaining two countries. Moreover, the effect has the same magnitude in Germany and France. If an online seller operates at most two brick stores, the effect on the likelihood of a price change is identical in Italy and France and significantly stronger than in Germany and the UK. In all countries it significantly lowers the likelihood of a price change. While the effect of retailers on the likelihood of a price change is insignificant in the UK and Germany, it is significant and negative in Italy and France (and the magnitude is statistically equal in both countries). The number of products offered by a seller has a negative significant impact on the likelihood of a price change in the UK but the impact is insignificant in all the remaining countries. On the other hand the percentage of shops that changed their price on the previous day is insignificant in the UK while it has the expected significant positive effect in the remaining countries under investigation. Finally, if the minimum price of a particular product changed on the previous day, the likelihood of a price change is significantly increased only in Germany. Similarly to the aggregate EU4 results, the lowest likelihood of a price change is obtained on Saturdays in all countries except for Germany where the day with the lowest likelihood of a price change is Friday. Out of the weekdays, Fridays have the lowest likelihood of price change in all countries except for the UK where the lowest likelihood was recorded on Mondays. In spite of the fact that firms are not allowed to change prices on Kelkoo on Sundays, there is no evidence that firms would bring forward price changes ahead of the weekend, on the contrary. France and the UK experience the highest likelihood of a price change on Tuesdays, Germany on Wednesdays and Italy on Thursdays.

An interesting conclusion that emerges from the analysis is the asymmetric behaviour of retailers in the European countries and in the US. While retailers in the EU4 countries exhibit lower odds of a price change than genuine web stores, ${ }^{31}$ the opposite holds true for the US. This finding can help us reconcile the differences in frequencies of price change when comparing conventional CPI prices in the US and the European countries (see section 3.6) with the finding of much smaller discrepancy in the frequency of price adjustment when comparing Internet prices across the US and the European countries (section 3.1).

\subsection{Results for identical digital cameras}

We run similar logistic regressions also on a subsample of matched digital cameras sold in all five countries (see also section 3.7). The specifications follow models (1) and (2), except for the obviously inappropriate variables, such as the product category indicators. The results are reported in table 9 below.

Let us first compare the results for model (1) obtained in the restricted subsample of identical digital cameras with the results for all products presented in table 8 . In spite of the very limited

31 The effect is not significant in Germany and the UK. 
product heterogeneity, the odds of a price change are significantly decreasing in the duration of a price spell (as it is the case in models for the US, UK and Germany). Of course, the use of separate shop type identifiers and control for basic general shop characteristics (e.g. by means of a size proxy) does not yield a perfectly homogeneous outlet structure. Based on their analysis of French micro CPI data, Fougère et al. (2005) find heterogeneity in the shape of the hazard function across outlet types.

With regard to time-dependent factors, we do not find a significant change in the odds of a price change at price spell duration of 1 week, which is consistent with the results for the all product specifications. Table 9 reveals significant differences in the likelihood of a price change across weekdays, as it is the case in the all product sample. The odds of a price change are highest on Thursdays, followed by Fridays, Wednesdays, Mondays and Tuesdays. As in the full product sample, the odds of a price change are significantly higher on any workday than on the weekend. More specifically, relative to Saturday, the odds of a price change ceteris paribus roughly double during the workdays. In addition, our results confirm that "attractive prices" lead to significantly lower odds of a price change. The number of sellers adds to the odds of a price change as in the all product sample, but the coefficient is statistically insignificant in this case. In analogy to the full product sample, we find significant differences across shop types. Similarly to the case of the all product sample in the US, retailers have higher odds of a price change than genuine online stores. In addition, in the subsample of identical digital cameras, also manufacturers exhibit significantly higher odds of a price change than genuine web sellers. Internet sellers maintaining at most two selling points (pick-up points/showrooms) have lower odds of price change than genuine web stores as in the all product sample, however, the difference is not anymore statistically significant. Finally, and similarly to the results for the all product sample, mail order companies exhibit the lowest likelihood of a price change by cutting the odds of a price change in less than half. The likelihood of a price change depends on the relative price level of a given product-shop combination in a similar way as in the all product sample. The highest likelihood of price change is obtained for shops charging particularly competitive prices (i.e. in the lowest quartile of the distribution of prices) while the lowest odds of a price change are observed for prices above the median of the price distribution. Contrary to our results for the all product sample, a larger number of products offered by a given shop significantly increases the odds of a price change. At the same time, a larger share of price changes on the previous day significantly diminishes the odds of a price change which again works in the opposite direction than in the full product sample. Finally, we find that the odds of a price change are significantly affected by the size of the preceding price change. Regardless whether the preceding price change lead to a price reduction or to a price increase, the larger its size, the smaller the likelihood of a price change.

The separate regressions for price increases (dependent variable $\left.y_{i j t}^{+}\right)$and price reductions $\left(y_{i j t}^{-}\right)$ illustrate in more detail how state-dependent and time-dependent factors influence the likelihood of price changes in different directions. Whereas most of the results described for the model on price changes apply to both price reductions and price increases, some "asymmetries" emerge. For example, our results suggest that the odds of a price increase (reduction) are significantly increased (reduced) if the preceding price change represented a price reduction. In addition, the larger the size of the preceding price increase (reduction), the smaller the likelihood of a price increase (reduction). These effects conform to our expectations. Whereas the odds of a price reduction are highest on Fridays, the likelihood of a price increase is highest on Thursdays. Attractive prices seem to significantly diminish the likelihood of a price increase but they do not significantly affect the likelihood of a price reduction in this model. 
Table 9: Logit estimates for identical models (odds ratios)

\begin{tabular}{|c|c|c|c|}
\hline Country/Area & US+EU4 & US+EU4 & US+EU4 \\
\hline Dependent variable & $y_{i j t}$ & $y_{i j t}^{+}$ & $y_{i j t}^{-}$ \\
\hline \multicolumn{4}{|l|}{ Explanatory variable } \\
\hline \multicolumn{4}{|l|}{ Price spell characteristics } \\
\hline Length of price spell & $\begin{array}{l}0.699^{* \star \star} \\
(-18.59)\end{array}$ & $\begin{array}{l}0.69 * \star * \\
(-13.43)\end{array}$ & $\begin{array}{l}0.722^{\star \star \star} \\
(-15.50)\end{array}$ \\
\hline Duration 1 week & $\begin{array}{r}0.92 \\
(-0.87)\end{array}$ & $\begin{array}{l}0.81 \\
(-1.50)\end{array}$ & $\begin{array}{r}1.03 \\
(0.30)\end{array}$ \\
\hline \multicolumn{4}{|l|}{ Price level characteristics } \\
\hline Attractive price & $\begin{array}{l}0.85^{\text {***}} \\
(-3.27)\end{array}$ & $\begin{array}{l}0.75^{\text {*** }} \\
(-3.94)\end{array}$ & $\begin{array}{r}0.91 \\
(-1.85)\end{array}$ \\
\hline Mid-low price level & $\begin{array}{l}0.84 \\
(-3.65)\end{array}$ & $\begin{array}{c}0.62 \\
(-6.84)\end{array}$ & $\begin{array}{r}0.94 \\
(-1.19)\end{array}$ \\
\hline Mid-high price level & $\begin{array}{c}0.70^{* * *} \\
(-5.96)\end{array}$ & $\begin{array}{c}0.83 \\
(-2.41)\end{array}$ & $\begin{array}{l}0.66 \text { *** } \\
(-6.25)\end{array}$ \\
\hline High price level & $\begin{array}{c}0.77^{* * \star} \\
(-3.52)\end{array}$ & $\begin{array}{c}0.56 \\
(-5.41)\end{array}$ & $\begin{array}{r}0.99 \\
(-0.07)\end{array}$ \\
\hline \multicolumn{4}{|l|}{ Weekday fixed effects } \\
\hline Monday & $\begin{array}{l}1.93^{* \star \star} \\
(8.86)\end{array}$ & $\begin{array}{l}2.60 \text { *** } \\
(8.33)\end{array}$ & $\begin{array}{l}1.57^{\star \star *} \\
(5.93)\end{array}$ \\
\hline Tuesday & $\begin{array}{l}1.89^{\star \star \star *} \\
(8.64)\end{array}$ & $\begin{array}{l}2.77^{\text {***}} \\
(9.02)\end{array}$ & $\begin{array}{l}1.42 \text { *** } \\
(4.62)\end{array}$ \\
\hline Wednesday & $\begin{array}{l}2.03 \\
(9.76)\end{array}$ & $\begin{array}{l}3.10^{* * *} \\
(10.20)\end{array}$ & $\begin{array}{l}1.37^{* * *} \\
(4.19)\end{array}$ \\
\hline Thursday & $\begin{array}{l}2.59 \\
(13.21)\end{array}$ & $\begin{array}{c}4.67 \\
(14.24)\end{array}$ & $\begin{array}{l}1.67 \\
(6.87)\end{array}$ \\
\hline Friday & $\begin{array}{l}2.16 \text { *** } \\
(10.61)\end{array}$ & $\begin{array}{l}2.28^{* \star *} \\
(7.06)\end{array}$ & ${ }^{1.88^{* * *}}(8.69)^{*}$ \\
\hline \multicolumn{4}{|l|}{ Shop characteristics } \\
\hline Online shop with few selling points/showroom & $\begin{array}{r}0.93 \\
(-0.96)\end{array}$ & $\begin{array}{r}0.85 \\
(-1.56)\end{array}$ & $\begin{array}{r}0.89 \\
(-1.52)\end{array}$ \\
\hline Retailer & $\begin{array}{l}1.95 \\
(8.13)\end{array}$ & $\begin{array}{l}2.66 \text { *** } \\
(9.40)\end{array}$ & $\begin{array}{l}1.37^{* \star *} \\
(3.37)\end{array}$ \\
\hline Manufacturer & 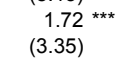 & $\begin{array}{c}2.21 \\
(4.07)\end{array}$ & $\begin{array}{r}1.05 \\
(0.25)\end{array}$ \\
\hline Mail order company & $\begin{array}{c}0.44 \\
(-5.60)\end{array}$ & $\begin{array}{r}0.44 \\
(-4.04)\end{array}$ & $\begin{array}{l}0.41^{* * *} \\
(-6.09)\end{array}$ \\
\hline Number of listings & $\begin{array}{l}1.00 \text { * } \\
(2.18)\end{array}$ & $\begin{array}{r}0.27 \\
(1.33)\end{array}$ & $\begin{array}{r}0.46 \\
(0.82)\end{array}$ \\
\hline \multicolumn{4}{|l|}{ Country fixed effects } \\
\hline Germany & 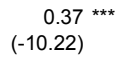 & $\begin{array}{r}1.00 \\
(-10.50)\end{array}$ & $\begin{array}{r}1.00^{* * *} \\
(-3.82)\end{array}$ \\
\hline France & $\begin{array}{l}0.32 \text { *** } \\
(-7.20)\end{array}$ & $\begin{array}{l}0.98 \text { *** } \\
(-5.98)\end{array}$ & $\begin{array}{l}0.99^{* * *} \\
(-4.46)\end{array}$ \\
\hline Italy & $\begin{array}{c}0.73^{\text {*** }} \\
(-4.28)\end{array}$ & $\begin{array}{c}1.03 \\
(-5.19)\end{array}$ & $\begin{array}{r}1.08 \text { * } \\
(-2.50)\end{array}$ \\
\hline US & $\begin{array}{l}2.16 \text { ** } \\
(3.09)\end{array}$ & $\begin{array}{l}0.17^{* * *} \\
(0.69)\end{array}$ & $\begin{array}{c}0.67 \text { * } \\
(2.27)\end{array}$ \\
\hline \multicolumn{4}{|l|}{ Characteristics of the previous price change } \\
\hline Size of previous price increase & $\begin{array}{l}0.99 \text { ** } \\
(-3.21)\end{array}$ & $\begin{array}{l}0.96 \text { *** } \\
(-6.20)\end{array}$ & $\begin{array}{r}1.00 \\
(0.03)\end{array}$ \\
\hline Size of previous price reduction & $\begin{array}{l}0.97 \\
(-6.38)\end{array}$ & $\begin{array}{l}1.01 \\
(2.12)\end{array}$ & $\begin{array}{l}0.95 \\
(-8.85)\end{array}$ \\
\hline Price reduction & $\begin{array}{r}1.09 \\
(2.03)\end{array}$ & $\begin{array}{l}1.688^{* * *} \\
(8.89)\end{array}$ & $\begin{array}{c}0.83^{* * *} \\
(-4.37)\end{array}$ \\
\hline Others & & & \\
\hline Number of sellers & $\begin{array}{r}1.00 \\
(1.67)\end{array}$ & $\begin{array}{l}1.00 * \\
(2.27)\end{array}$ & $\begin{array}{r}1.00 \\
(1.72)\end{array}$ \\
\hline Percentage prices changed/increased/decreased in $t-1$ & $\begin{array}{c}0.99 \\
(-4.93)\end{array}$ & $\begin{array}{c}0.62 \\
(-3.55)\end{array}$ & $\begin{array}{r}0.81 \\
(-2.68)\end{array}$ \\
\hline Minimum price changed/increased/decreased in $t-1$ & $\begin{array}{r}1.04 \\
(0.76)\end{array}$ & $\begin{array}{r}1.25 \\
(0.28)\end{array}$ & $\begin{array}{r}1.60 \\
(1.09)\end{array}$ \\
\hline Intercept & $\begin{array}{r}0.22 \\
(-12.66)\end{array}$ & $\begin{array}{l}0.05 \\
(-18.34)\end{array}$ & $\begin{array}{c}0.15 \\
(-15.28)\end{array}$ \\
\hline Number of observations & 34556 & 34556 & 34556 \\
\hline
\end{tabular}

Note: The table lists odds ratios, z-statistics in parentheses. ${ }^{* * *} /{ }^{* * *}$ indicate significance at the 5/1/0.1 percent level, respectively. Results relative to Saturday/DVD players/UK.

In addition, our results suggest that the likelihood of a price increase is significantly higher for manufacturers than for genuine web stores, whereas we do not find a significant difference in the case of price decreases. Moreover, the likelihood of both a price reduction and a price increase is significantly higher for retailers than for genuine web stores, but the effect is much stronger for a price increase than for a price reduction, other things equal. Finally, the separate regressions for price reductions and price increases suggest that whereas the likelihood of a 
price increase is lower in the US than in the UK (though not statistically distinguishable), the odds of a price reduction are ceteris paribus significantly higher in the US. In contrast, all European countries exhibit a significantly smaller likelihood of both price reductions and price increases relative to the UK, all else equal.

\section{Conclusion}

The study leads to the following conclusions. First, Internet prices in the EU4 countries change on average more often than online prices in the US. This is in contrast to the recent findings from the micro price studies that univocally find more rigid prices in Europe using CPI data. Whereas retailers in the US might face smaller impediments to price adjustment than their EU4 counterparts, this does not seem to be the case for genuine online stores. To the extent that cross-country differences in the degree of regulation were to be smaller on the Internet than in the traditional retailing (directly or indirectly, e.g. through smaller labour intensity), this can be interpreted as indirect evidence suggesting that price stickiness in the euro area's traditional retail sector can be at least partially explained by a more intrusive regulatory framework as compared to the US. Second, prices on the Internet are not necessarily more flexible than prices in the traditional brick-and-mortar stores. On average, more than half of all Internet price spells fails within one month and on average 2.6 percent of Internet price quotes are changed every day. In the US, however, we find several product categories for which Internet prices last on average longer than the implied duration of off-line prices reported in existing research. This contradicts the prediction of the menu cost hypothesis given the lower cost of a price change on the Internet. In Germany, however, Internet prices last substantially shorter than the implied duration of off-line prices. In this context, with an increasing share of products sold via the Internet, a simple analysis of conventional brick store prices may - to an increasing degree lead to underestimation of the true degree of consumer price flexibility.

Third, we found a substantial degree of heterogeneity across shop types and product categories. Mail order companies and TV shops have the lowest likelihood of a price change, all else equal. This is in line with the prediction of the menu cost hypothesis based on the observation that these two shop types exhibit the highest cost of a price change among the shop types considered. The same argument implies that genuine Internet sellers should have the highest likelihood of a price change. This holds true with the exception of retailers in the US. Differences in the frequency of price change across product categories are more pronounced than differences across countries. Whereas this finding is well in line with findings from recent evidence from the analysis of CPI data in euro area countries, within the context of our study, it applies to a narrower set of consumer products and when taking into account data for the US.

Fourth, the average size of price changes on the Internet is relatively large (5.4\%). Nevertheless, it is smaller than the respective values reported in the CPI data. Moreover, the most common price change interval on the Internet ranges from 0 to -1 percent, while in the $\mathrm{CPI}$ data one observes very few price changes in the interval from -2.5 to 2.5 percent. This corresponds to the prediction of the menu cost hypothesis.

Lastly, the panel logit estimates suggest that the likelihood of a price change is a function of both state- and time-dependent factors. In particular, the likelihood of a price change increases with the number of sellers offering the particular product and the percentage of sellers that changed the price of the same product on the previous day. Attractive prices, such as $€ 9.99$, and price quotes with high relative price level exhibit lower likelihood of a price change, all else equal. In general, the results also hold in a subsample of identical products sold in all countries. 
References

Allen, F. (1988): "A Theory of Price Rigidities when Quality is Unobservable", Review of Economic Studies, Vol. 55, pp. 139-151.

Álvarez, L. J. and I. Hernando (2006): "Price Setting Behaviour in Spain: Evidence from Consumer Price Micro-Data", Economic Modelling (forthcoming).

Álvarez, L. J., E. Dhyne, M. Hoeberichts, C. Kwapil, H. Le Bihan, P. Lünnemann, F. Martins, R. Sabbatini, H. Stahl, P. Vermeulen and J. Vilmunen (2005a): "Sticky prices in the euro area: a summary of new micro-evidence", Journal of the European Economic Association (forthcoming).

Álvarez, L., P. Burriel, and I. Hernando (2005b): "Do Decreasing Hazard Functions Make Sense?", ECB Working Paper No. 461.

Álvarez, L. J., P. Burriel and I. Hernando (2005c): "Price Setting Behaviour in Spain: Evidence From Micro PPI Data", ECB Working Paper No. 522.

Aucremanne, L. and E. Dhyne (2004): "How Frequently Do Prices Change? Evidence Based on the Micro Data Underlying the Belgian CPI", ECB Working Paper No. 331.

Aucremanne, L. and E. Dhyne (2005): "Time-Dependent versus State-Dependent Pricing: A Panel Data Approach to the Determinants of Belgian Consumer Price Changes", ECB Working Paper No. 462.

Baudry, L., H. Le Bihan, P. Sevestre and S. Tarrieu (2004): "Price Rigidity: Evidence from the French CPI Micro-Data", ECB Working Paper No. 384.

Baumgartner, J., E. Glatzer, F. Rumler and A. Stiglbauer (2005): "How frequently do consumer prices change in Austria? Evidence from micro CPI data", ECB Working Paper No. 523.

Baye, W. R., J. Morgan and P. Scholten (2002): "Price Dispersion in the Small and in the Large: Evidence from an Internet Price Comparison Site", Journal of Industrial Economics, Vol. 52(4), pp. 463-496.

Bergen, M., D. Levy, S. Ray, P. H. Rubin and B. Zeliger (2004): "When Little Things Mean a Lot: On the Inefficiency of Item Pricing Laws", Emory Law and Economics Research Paper No. 0408 .

Bergen, M., R. J. Kauffman and D. Lee (2005): "How Rigid Are Prices in E-Commerce? An Analysis of Daily Price Change Activity in Internet Retailing", in R. Sprague (Ed.) (2005): "Proceedings of the 38th Hawaii Intl. Conf. on Systems Science", Kona, HI, IEEE Comp. Soc. Press, Los Alamitos, CA.

Bils, M. and P. Klenow (2004): "Some Evidence on the Importance of Sticky Prices", Journal of Political Economy, Vol. 112, No. 5, pp. 947-985.

Blinder, A. S., E. R. D. Canetti, D. E. Lebow, and J. B. Rudd (1998): "Asking About Prices: A New Approach to Understanding Price Stickiness”, Russell Sage Foundation, New York.

Borenstein, S., C. Cameron and R. Gillbert (1997): "Do Gasoline Prices Respond Asymmetrically to Crude Oil Price Changes", Quarterly Journal of Economics, Vol. 112, pp. 305-339.

Burstein, A., M. Eichenbaum and S. Rebelo (2005): "Large Devaluations and the Real Exchange Rate", Journal of Political Economy, Vol. 113, No. 4.

Brynjolfsson, E. and M. Smith (2000): "Frictionless Commerce? A Comparison of Internet and Conventional Retailers," Management Science, Vol. 46, No. 4. 
Campbell, J. R. and B. Eden (2005): "Rigid Prices: Evidence from US Scanner Data", Federal Reserve Bank of Chicago WP 2005-08.

Cecchetti, S. (1986): "The Frequency of Price Adjustment: A Study of the Newsstand Prices of Magazines", Journal of Econometrics, Vol. 31, pp. 255-274.

Chakrabarti, R. and B. Scholnick (2005): "Nominal rigidities without literal menu costs: evidence from E-commerce", Economics Letters, Volume 86, Issue 2, pp. 187-191.

Chevalier, J. and A. Goolsbee (2003): "Measuring Prices and Price Competition Online: Amazon vs. Barnes and Noble", Quantitative Marketing and Economics, June, 1, pp. 203-222.

Clarida, R., J. Galí and M. Gertler (1999): "The Science of Monetary Policy", Journal of Economic Literature, Vol. 37, No. 4, pp. 1661-1707.

Dhyne, E., L. Álvarez, H. Le Bihan, G. Veronese, D. Dias, J. Hoffmann, N. Jonker, P. Lünnemann, F. Rumler and J. Vilmunen (2005): "Price setting in the Euro Area: Some Stylised Facts From Micro Consumer Price Data", ECB Working Paper No. 524.

Dutta, S., M. Bergen, D. Levy and R. Venable (1999): "Menu Costs, Posted Prices, and Multiproduct Retailers", Journal of Money, Credit, and Banking, Vol. 31(4), pp. 683-703.

Dutta, S., M. Bergen and D. Levy (2002): "Price Flexibility in Channels of Distribution: Evidence from Scanner Data", Journal of Economic Dynamics \& Control, Vol. 26, pp. 1845-1900.

Ellison, G. and S. F. Ellison (2005): "Lessons About Markets from the Internet", Journal of Economic Perspectives, Vol. 19, Number 2, pp. 139-158.

Fabiani, S., M. Druant, I. Hernando, C. Kwapil, B. Landau, C. Loupias, T. Mathä, R. Sabbatini, H. Stahl and A. Stokman (2005): "The Pricing Behaviour of Firms in the Euro Area: New Survey Evidence”, ECB Working Paper No. 535.

Fougère, D, H. Le Bihan and P. Sevestre (2005): "Heterogeneity in consumer price stickiness: a microeconometric investigation", ECB Working Paper No. 536.

Hoffmann, J. and J.-R. Kurz-Kim (2006): "Consumer price adjustment under the microscope: Germany in a period of low inflation", ECB Working Paper (forthcoming).

Kashyap, A. (1995): "Sticky Prices: New Evidence from Retail Catalogues", Quarterly Journal of Economics, Vol. 105, No. 1, pp. 245-274.

Kauffman, R.J. and C.A. Wood (2000): "Follow the leader? Strategic pricing in e-commerce", in "Proceedings of the $21^{\text {st }}$ international conference on Information systems", Association for Information Systems, Atlanta, GA.

Lach, S. and D. Tsiddon (1992): "The Behaviour of Prices and Inflation: An Empirical Analysis of Disaggregated Price Data", Journal of Political Economy, Vol. 100, pp. 349-389.

Levy, D., M. Bergen, S. Dutta and R. Venable (1997): "The Magnitude of Menu Costs: Direct Evidence from Large U.S. Supermarket Chains", Quarterly Journal of Economics, Vol. CXII, 791-825.

Lünnemann, P. and T. Mathä (2005a): "Nominal rigidities and inflation persistence in Luxembourg: A comparison with EU 15 member countries with particular focus on services and regulated prices", Banque centrale du Luxembourg Cahier d'Études No. 14.

Lünnemann, P. and T. Mathä (2005b): "Consumer Price Behaviour in Luxembourg: Evidence from micro CPI data", Banque centrale du Luxembourg Cahier d'Études No. 17.

Ratfai, A. (2003): "The Frequency and Size of Price Adjustments: Microeconomic Evidence", mimeo, Central European University (Budapest). 
Raju, J., R. K. Sethuraman and S.K. Dhar (1995): "The Introduction and Performance of Store Brands", Management Science, Vol. 41, pp. 957 - 978.

U.S. Census Bureau (2005): "Quarterly Retail E-Commerce Sales $3{ }^{\text {rd }}$ Quarter 2005".

Vermeulen P., D. Dias, M. Dossche, I. Hernando, R. Sabbatini, H. Stahl and P. Sevestre (2006): "Price setting in the euro area: some stylised facts from individual producer price data", mimeo, European Central Bank (Frankfurt).

Veronese G., Fabiani S. and R. Sabbatini (2005): "Consumer Price Behaviour in Italy - Evidence from Micro CPI Data", ECB Working Paper No. 449.

Warner, E. J. and R. B. Barsky (1995): "The Timing and Magnitude of Retail Store Markdowns: Evidence from Weekends and Holidays", Quarterly Journal of Economics, Vol. 110, No. 2, pp. 321-352. 


\section{Appendix A}

Table A1: Sensitivity analysis of estimates of model (1) for the EU4 countries (odds ratios)

\begin{tabular}{|c|c|c|}
\hline Country/Area & & EU4 \\
\hline Dependent variable & & yijt \\
\hline \multicolumn{3}{|l|}{ Explanatory variable } \\
\hline \multicolumn{3}{|l|}{ Price spell characteristics } \\
\hline Length of price spell & & $0.85^{* * *}$ \\
\hline & ID Germany & 0.97 \\
\hline & ID France & $1.30^{* * *}$ \\
\hline & ID Italy & $1.23^{\star \star *}$ \\
\hline Duration 1 week & & 1.08 \\
\hline \multicolumn{3}{|l|}{ Price level characteristics } \\
\hline Attractive price & & $0.73^{* * *}$ \\
\hline Mid-low price level & & 0.94 \\
\hline & ID France & 0.85 \\
\hline Mid-high price level & & $0.90 *$ \\
\hline High price level & & $0.87^{* *}$ \\
\hline \multicolumn{3}{|l|}{ Weekday fixed effects } \\
\hline \multicolumn{3}{|l|}{ Monday } \\
\hline \multirow{5}{*}{ Tuesday } & ID France & $4.83^{* * *}$ \\
\hline & & $5.19^{* * *}$ \\
\hline & ID Germany & $0.53^{\star \star \star}$ \\
\hline & ID France & 2.85 *** \\
\hline & ID Italy & $0.49 * * *$ \\
\hline \multirow[t]{3}{*}{ Wednesday } & & $2.82^{* * *}$ \\
\hline & ID France & $2.63^{* \star *}$ \\
\hline & ID Italy & 0.61 ** \\
\hline \multirow[t]{4}{*}{ Thursday } & & $3.49^{* * *}$ \\
\hline & ID Germany & $0.62 * * *$ \\
\hline & ID France & $2.11^{\star \star *}$ \\
\hline & ID Italy & $0.49^{* * *}$ \\
\hline \multirow[t]{3}{*}{ Friday } & & $2.67^{* * *}$ \\
\hline & ID Germany & $0.02^{* * *}$ \\
\hline & ID Italy & $0.53^{* * *}$ \\
\hline \multicolumn{3}{|l|}{ Shop characteristics } \\
\hline \multicolumn{2}{|c|}{ Online shop with few selling points/showroom } & 0.76 ** \\
\hline & ID France & 0.68 ** \\
\hline \multirow{2}{*}{\multicolumn{2}{|c|}{ Retailer }} & $0.58 *$ \\
\hline & & 0.96 \\
\hline & ID France & $0.58^{* \star *}$ \\
\hline & ID Italy & $0.63 *$ \\
\hline \multicolumn{2}{|l|}{ Manufacturer } & 0.58 \\
\hline \multirow{2}{*}{\multicolumn{2}{|c|}{ Mail order company }} & $0.38^{* *}$ \\
\hline \multirow{2}{*}{\multicolumn{2}{|c|}{ Number of listings }} & 0.99 ** \\
\hline & & $1.00^{* *}$ \\
\hline & ID France & $1.00 *$ \\
\hline & ID Italy & 1.00 ** \\
\hline \multicolumn{3}{|l|}{ Country fixed effects } \\
\hline \multicolumn{2}{|l|}{ Germany } & $0.60 *$ \\
\hline \multirow{2}{*}{\multicolumn{2}{|c|}{$\begin{array}{l}\text { France } \\
\text { Italy }\end{array}$}} & $0.14^{* * *}$ \\
\hline & & 0.78 \\
\hline Others & & \\
\hline Number of sellers & & $0.99^{* * *}$ \\
\hline & ID Germany & 1.03 ** \\
\hline & ID France & 1.03 ** \\
\hline Percentage prices cha & ged in $t-1$ & $0.99 * * *$ \\
\hline & ID Germany & $1.01^{* * *}$ \\
\hline & ID France & $1.01 * * *$ \\
\hline & ID Italy & $1.01^{* * *}$ \\
\hline Change to minimum pr & ce in $t-1$ & 0.89 \\
\hline & ID Germany & $1.41^{* *}$ \\
\hline Intercept & & $0.04^{* * *}$ \\
\hline
\end{tabular}

Note: The table lists odds ratios, ${ }^{* / * * / * *}$ indicate significance at the $5 / 1 / 0.1$ percent level, respectively. ID stands for country interaction variable (i.e. the particular independent variable times the country dummy). Results for EU4 relative to Saturday/DVD players/UK. Product category fixed effects not included. 


\section{European Central Bank Working Paper Series}

For a complete list of Working Papers published by the ECB, please visit the ECB's website (http://www.ecb.int)

594 “The euro's trade effects" by R. Baldwin, comments by J. A. Frankel and J. Melitz, March 2006

595 "Trends and cycles in the euro area: how much heterogeneity and should we worry about it?" by D. Giannone and L. Reichlin, comments by B. E. Sørensen and M. McCarthy, March 2006.

596 "The effects of EMU on structural reforms in labour and product markets" by R. Duval and J. Elmeskov, comments by S. Nickell and J. F. Jimeno, March 2006.

597 "Price setting and inflation persistence: did EMU matter?" by I. Angeloni, L. Aucremanne, M. Ciccarelli, comments by W. T. Dickens and T. Yates, March 2006.

598 "The impact of the euro on financial markets" by L. Cappiello, P. Hördahl, A. Kadareja and S. Manganelli, comments by X. Vives and B. Gerard, March 2006.

599 "What effects is EMU having on the euro area and its Member Countries? An overview" by F. P. Mongelli and J. L. Vega, March 2006.

600 "A speed limit monetary policy rule for the euro area" by L. Stracca, April 2006.

601 "Excess burden and the cost of inefficiency in public services provision" by A. Afonso and V. Gaspar, April 2006.

602 "Job flow dynamics and firing restrictions: evidence from Europe" by J. Messina and G. Vallanti, April 2006.

603 "Estimating multi-country VAR models" by F. Canova and M. Ciccarelli, April 2006.

604 "A dynamic model of settlement" by T. Koeppl, C. Monnet and T. Temzelides, April 2006.

605 “(Un)Predictability and macroeconomic stability” by A. D’Agostino, D. Giannone and P. Surico, April 2006.

606 "Measuring the importance of the uniform nonsynchronization hypothesis" by D. A. Dias, C. Robalo Marques and J. M. C. Santos Silva, April 2006.

607 "Price setting behaviour in the Netherlands: results of a survey" by M. Hoeberichts and A. Stokman, April 2006.

608 "How does information affect the comovement between interest rates and exchange rates?" by M. Sánchez, April 2006.

609 "The elusive welfare economics of price stability as a monetary policy objective: why New Keynesian central bankers should validate core inflation" by W. H. Buiter, April 2006.

610 "Real-time model uncertainty in the United States: the Fed from 1996-2003" by R. J. Tetlow and B. Ironside, April 2006.

6II "Monetary policy, determinacy, and learnability in the open economy" by J. Bullard and E. Schaling, April 2006. 
612 "Optimal fiscal and monetary policy in a medium-scale macroeconomic model" by S. Schmitt-Grohé and M. Uribe, April 2006.

613 "Welfare-based monetary policy rules in an estimated DSGE model of the US economy" by M. Juillard, P. Karam, D. Laxton and P. Pesenti, April 2006.

$6 / 4$ "Expenditure switching vs. real exchange rate stabilization: competing objectives for exchange rate policy" by M. B. Devereux and C. Engel, April 2006.

615 "Quantitative goals for monetary policy" by A. Fatás, I. Mihov and A. K. Rose, April 2006.

616 "Global financial transmission of monetary policy shocks" by M. Ehrmann and M. Fratzscher, April 2006.

617 "New survey evidence on the pricing behaviour of Luxembourg firms" by P. Lünnemann and T. Y. Mathä, May 2006.

618 "The patterns and determinants of price setting in the Belgian industry" by D. Cornille and M. Dossche, May 2006.

619 "Cyclical inflation divergence and different labor market institutions in the EMU" by A. Campolmi and E. Faia, May 2006.

620 "Does fiscal policy matter for the trade account? A panel cointegration study" by K. Funke and C. Nickel, May 2006.

621 "Assessing predetermined expectations in the standard sticky-price model: a Bayesian approach" by P. Welz, May 2006.

622 "Short-term forecasts of euro area real GDP growth: an assessment of real-time performance based on vintage data" by M. Diron, May 2006.

623 "Human capital, the structure of production, and growth" by A. Ciccone and E. Papaioannou, May 2006.

624 "Foreign reserves management subject to a policy objective" by J. Coche, M. Koivu, K. Nyholm and V. Poikonen, May 2006.

625 "Sectoral explanations of employment in Europe: the role of services" by A. D'Agostino, R. Serafini and M. Ward-Warmedinger, May 2006.

626 "Financial integration, international portfolio choice and the European Monetary Union" by R. A. De Santis and B. Gérard, May 2006.

627 "Euro area banking sector integration: using hierarchical cluster analysis techniques" by C. Kok Sørensen, J. M. Puigvert Gutiérrez, May 2006.

628 "Long-run money demand in the new EU Member States with exchange rate effects" by C. Dreger, H.-E. Reimers and B. Roffia, May 2006.

629 "A market microstructure analysis of foreign exchange intervention" by P. Vitale, May 2006.

630 “Implications of monetary union for catching-up member states” by M. Sánchez, May 2006.

631 "Which news moves the euro area bond market?" by M. Andersson, L. J. Hansen and S. Sebestyén, May 2006. 
632 "Does information help recovering structural shocks from past observations?" by D. Giannone and L. Reichlin, May 2006.

633 "Nowcasting GDP and inflation: the real-time informational content of macroeconomic data releases" by D. Giannone, L. Reichlin and D. H. Small, May 2006.

634 "Expenditure reform in industrialised countries: a case study approach" by S. Hauptmeier, M. Heipertz and L. Schuknecht, May 2006.

635 "Identifying the role of labor markets for monetary policy in an estimated DSGE model" by K. Christoffel, K. Kuester and T. Linzert, June 2006.

636 "Exchange rate stabilization in developed and underdeveloped capital markets" by V. Chmelarova and G. Schnabl, June 2006.

637 “Transparency, expectations, and forecasts" by A. Bauer, R. Eisenbeis, D. Waggoner and T. Zha, June 2006.

638 “Detecting and predicting forecast breakdowns” by R. Giacomini and B. Rossi, June 2006.

639 "Optimal monetary policy with uncertainty about financial frictions” by R. Moessner, June 2006.

640 “Employment stickiness in small manufacturing firms” by P. Vermeulen, June 2006.

641 "A factor risk model with reference returns for the US dollar and Japanese yen bond markets" by C. Bernadell, J. Coche and K. Nyholm, June 2006.

642 “Financing constraints and firms' cash policy in the euro area” by R. Pál and A. Ferrando, June 2006.

643 "Inflation forecast-based-rules and indeterminacy: a puzzle and a resolution" by P. Levine, P. McAdam and J. Pearlman, June 2006.

644 “Adaptive learning, persistence, and optimal monetary policy” by V. Gaspar, F. Smets and D. Vestin, June 2006.

645 “Are internet prices sticky?” by P. Lünnemann and L. Wintr, June 2006. 
